\title{
Creating a Common Law of Slavery for England and its New World Empire
}

\author{
HOLLY BREWER
}

Between 1667 and 1671, the Royal African Company (RAC) went bankrupt. ${ }^{1}$ It did so despite extensive royal patronage and connections-its

1. The full name of the Royal African Company was originally "The Company of Royal Adventurers into Africa" but it was formally shortened in 1672 and informally shortened earlier. See George Frederick Zook, The Company of Royal Adventurers Trading into Africa [1919] (New York: Negro Universities Press, 1969).

Holly Brewer is Burke Professor of American History and Associate Professor at the University of Maryland <hbrewer@umd.edu>. Earlier versions of this article date to March 2010. It has been part of a larger book project, and this research re-oriented the entire direction of my book in complex ways, forcing me to ask entirely different questions about the role of empire in the development of slave law. I shared it first with Jack Greene, Mia Bay, Barry Gaspar, Peter Wood, Chris Tomlins, and David Konig, all of whom I particularly wish to thank for their feedback at that early stage, as well as Jim Oldham, Lorena Walsh, and Mitch Fraas. I received support for this research from the National Endowment for Humanities, the National Humanities Center, the Guggenheim foundation, and the William Nelson Cromwell Foundation. I presented it as a keynote at the British Group of Early American Historians in September 2010 as "Before Somerset: Debating Slavery and Absolutism in England and its Early Empire" available at SSRN. That version was shared with Joseph Murphy and James Oakes that September and with John Blanton in March 2011, all at CUNY. I shared it at the Omohundro Institute Colloquium in January 2011, and the Triangle Legal History Consortium (May 2011). In 2012, I gave it as an oral presentation (then called "Twelve Judges in Scarlet" at U Penn Law School, also available on SSRN. I presented it as a precirculated paper at Yale Law School (2014), by then with its current title "Creating a Common Law of Slavery" which 
governor and main shareholders all belonged to the royal family. It did so despite having monopoly power to import African "servants" to the English colonies, free use of royal navy ships, access to royal forts off the African coast, and royal proclamations providing incentives to colonists to purchase the African "servants" that the company imported. It did so despite the king's encouragement of slave codes and local debt collection processes in each colony that favored "so Royall a Compagnie." ${ }^{2}$ One might be tempted to proclaim that the RAC's failure shows the weaknesses of royal policy and indeed of mercantilism itself. But in fact the problem that caused the bankruptcy was identified and resolved by one further, and major, royal effort: after the company went bankrupt, Charles II helped to make the buying and selling of people as slaves both fully legal and enforceable across the empire. When Parliament failed to pass an imperial slave code with such provisions, he turned to the courts. Charles II's judges - "his" judges in the sense that they held their seats "during his pleasure" - presided over a series of rulings that made slavery legal not only in England itself, but also in its empire. These judges held that people could be "goods" or absolute property if they were "infidels" (and therefore legally aliens), and that their status could be perpetual and hereditary. These rulings brought the phalanx of English property law to support slavery.

In the seventeenth century the English common law became an instrument - the best the Stuart kings of England had - to create new laws, in the form of new precedents, and thus to both expand their own power and to legitimate slavery. Common law is a precedent-based system

2. "Soe Royall a Compagnie" was Willoughby's expression in 1666, after factors for the company had reported him for not acting quickly enough on the company's behalf against an independent (and illegal) trader. Governor Lord Willoughby to the Privy Council, July 16, 1666 TNA (UK National Archives) CO 1/20, No. 121 (p. 1 of that letter).

they posted publicly to the web (on SSRN as well), and gave it as a presentation at the ASLH (2014) and at the British Legal History Conference (2015) and as a plenary to the same conference (2017). I presented it as a pre-circulated paper at the NYU law school seminar (2018) and particularly wish to thank Dan Hulsebosch and Bill Nelson for their feedback. In Spring 2019 I shared it with Jennifer L. Morgan's "Finance, Race, and Gender" seminar at the Folger Library; special thanks to Jennifer and Marisa J. Fuentes. I gave other versions of it at SHEAR in 2012 and 2018, and at the Business History Conference (2018). Finally I shared the near final version with my Omohundro Coffeehouse writing group and the Washington Early American Seminar (both 2021). I have received, throughout, many terrific questions and helpful feedback. This version is much revised, and I have chosen to leave earlier versions, which have already influenced other scholarship, on SSRN. 
often characterized as conservative, local, and relatively unchanging. The modern term is stare decisis, or the idea that courts uphold prior decisions or precedents. But precedent-based systems do sometimes create new precedents. Here justices created powerful legal mechanisms that made it possible to "recover" people as assets for debts, a legal definition that crown officials began to realize was essential for a market in people to function sucessfully. English high court judges thus provided the legal foundation for an imperial common law of slavery that allowed people to be deemed absolute property. That definition of people as property was closely connected to absolutism, both in theory and practice. In theory the absolute power of kings was connected to that of masters. In practice, the crown's use of the courts to create laws without parliamentary consent (to bypass parliament) also increased crown revenue and thus their independence from parliamentary control. This history reveals the absolutist character of early capitalism, and the extent to which the character of capitalist development depends on the legal rules that define markets and justice.

The current historical consensus is that English common law was somewhat confused, but that coerced servitude was legal in England before 1772, and certainly in its empire, where English law on slavery did not reach, because it was "beyond the line" of English justice. England's "free society" tolerated slavery only because it was distant and across the ocean. Occasionally the historiography goes back as far as the seventeenth or even sixteenth centuries, to cite obscure cases that might be construed as precedents for slavery, or even to the medieval period, when a kind of slavery was clearly legal in England itself. ${ }^{3}$ Mostly, however, the historical consensus has seen slavery disappearing during the late medieval period, and a consistent policy whereby England tolerated slavery in the colonies, but not at home. The common law is characterized by an effort to see continuity and consistency, and historians (despite our natural desire

3. A foundational article (still worth reading) is Edward Fiddes, "Lord Mansfield and the Somersett Case," Law Quarterly Review 50 (1934): 499-511. Also see F.O. Shylon, Black Slaves in Britain (London: Institute of Race Relations, 1974); William M. Wiecek, "Somerest: Lord Mansfield and the Legitimacy of Slavery in the Anglo-American World," University of Chicago Law Review 42 (1974): 86-146; David Brion Davis, The Problem of Slavery in the Age of Revolution (Ithaca, NY: Cornell University Press, 1975), ch. 10. Also see James Oldham, "New Light on Mansfield and Slavery," Journal of British Studies 27 (1988): 45-68, especially 48, who added new dimensions to our understanding of Somerset, in particular, and A. Leon Higginbotham, In the Matter of Color: Race and the American Legal Process I: The Colonial Period (Oxford: Oxford University Press, 1980), 323-27, who treated these earlier cases more seriously than other scholars, although his interpretation still rests in the shadow of Somerset. The current consensus aligns with the arguments in George Van Cleve, "Somerset's Case and Its Antecedents in Imperial Perspective," Law and History Review 24 (2006): 601-46. 
to track change) often look for those patterns too. Such efforts to provide a consistent overview of an England that was free and colonies that created slavery on their own has obscured the vibrant debate within the English judicial system over the legality of slavery in England and its empire over more than a century. Not only did the common law on slavery change profoundly during the seventeenth and eighteenth centuries: the common law became an instrument of crown policy. It provided a foundation for a common law of slavery in all English colonies and for the slave trade. It created a legal fiction-since people were not and are not actually things - upon which to base (and litigate) the ownership of people.

As a precedent-based system, England's common law system was supposed to incorporate and refer to laws passed by Parliament, and it was in some ways harder to shape than comparable civil law systems elsewhere in Europe, which gave dramatic scope to royal decrees. So in Spain the kings could revise the Siete Partidas; in France Louis XIV could issue a Code Noire (1685). Royal decrees could shape policies in their empires, even though they were imperfectly enforced. ${ }^{4}$ This article tells the strange but compelling history of how the kings of England, unable to simply issue royal decrees, used the courts to circumvent Parliament and to legitimate slavery, beginning with a 1677 case called Butts v. Penny. More generally, the courts under Charles II and James II, as under their father, Charles I, had often allowed English kings to circumvent Parliament, to ignore laws and to effectively create new ones. Courts became such crucial instruments of absolutism that after the revolution against James II in 1688, the revolutionary "Convention Parliament" that met in the spring of 1689 purged and punished all twelve high court justices of the common law courts and decreed that no decisions from James II's reign should ever be cited as precedent. The new cadre of justices after the Glorious Revolution, led by Sir John Holt, furthermore, sought to overturn the court's decisions on slavery from Charles II's reign. After King William's death and then his judges' deaths, however, those reversals would be in turn countermanded. When they left legal uncertainty around slavery, Parliament intervened in 1732 to ratify these crucial court decisions, at least for the colonies: there, people could be simple property

4. On Spain, see, for example, Linda M. Rupert, Creolization and Contraband: CuraCao in the Early Modern Atlantic World (Athens: University of Georgia Press, 2012); and Michelle A. McKinley, Fractional Freedoms: Slavery, Intimacy, and Legal Mobilization in Colonial Lima, 1600-1700 (Cambridge: Cambridge University Press, 2016). On the French Code Noir and its impact on the empire, see, for example, Sue Peabody, There Are No Slaves in France: The Political Culture of Race and Slavery in the Ancien Régime (Oxford: Oxford University Press, 1996); and Brett Rushforth, Bonds of Alliance: Indigenous and Atlantic Slaveries in New France (Chapel Hill: UNC Press, 2012). 
and recoverable like "goods" for debts. ${ }^{5}$ When, in 1772, Lord Mansfield held that James Somerset of Virginia was a free man "though the heavens may fall," and recalled the Holt court decisions, technically the decision did not impact Britain's colonies in the Americas, where their status as property had been secured by Parliamentary act. It did, however, challenge the logic of that earlier decision. Despite Somerset, and despite the revolution, the high court decisions from Charles II's reign would continue to define American slavery in the Southern states where it remained (and in those to which it expanded).

American slavery therefore did not emerge "beyond the line" of English justice, but within it. ${ }^{6}$ While colonial legislatures could and did make some

5. Claire Priest's interpretation of the 1732 Debt Recovery Act in her article on "Creating an American Property Law: Alienability and Its Limits in American History," Harvard Law Review 120 (2006/2007): 385-459, has been very helpful. She has recently expanded it into a book: Claire Priest, Credit Nation: Property Laws and Institutions in Early America (Princeton: Princeton University Press, 2021). Where we tend to disagree is on the extent to which these developments emerged from colonial (vs. imperial) concerns, as well as on the extent to which they were political (as opposed to economic) issues. For me the key concept is political economy (they are intimately connected).

6. Scholars who see it emerging largely outside English justice include Richard S. Dunn, Sugar and Slaves: The Rise of the Planter Class in the English West Indies, 1624-1713 (Chapel Hill: UNC Press, 2012); Daniel J. Hulsebosch, Constituting Empire: New York and the Transformation of Constitutionalism in the Atlantic World, 1664-1830 (Chapel Hill: UNC Press, 2006); Daniel J. Hulsebosch, "Somerset's Case at the Bar: Securing the Pure Air of English Jurisdiction within the British Empire Symposium Edition: Too Pure an Air: Law and the Quest for Freedom, Justice, and Equality: Essay," Texas Wesleyan Law Review 13 (2006/2007): 699-710; Jonathan A. Bush, "Free to Enslave: The Foundations of Colonial American Slave Law," Yale Journal of Law \& the Humanities 5 (1993): 417-70; Jerome S. Handler, "Custom and Law: The Status of Enslaved Africans in Seventeenth-Century Barbados," Slavery \& Abolition 37 (2016): 233-55; Van Cleve, "Somerset's Case and Its Antecedents in Imperial Perspective"; and Michael Guasco, Slaves and Englishmen, Slaves and Englishmen (Philadelphia: University of Pennsylvania Press, 2014). Christopher S. Tomlins is torn on this question as are many other scholars. Tomlins describes much more debate over the civil law of slavery in seventeenth-century England than do other scholars. A new book by Wilson on eighteenth-century South Carolina sees eighteenth-century South Carolina planters as building on English law, but with the English courts largely outside of that process: Lee B. Wilson, Bonds of Empire: The English Origins of Slave Law in South Carolina and British Plantation America, 1660-1783 (Cambridge: Cambridge University Press, 2021). Simon Newman strikes much the same balance: colonists were building on English law of servitude and villenage, but were doing so mostly on their own: Simon P. Newman, A New World of Labor: The Development of Plantation Slavery in the British Atlantic (Philadelphia: University of Pennsylvania Press, 2013). That is also largely the perspective taken by American legal historians who focus on the common law: see, for example, William Edward Nelson, Americanization of the Common Law: The Impact of Legal Change on Massachusetts Society, 1760-1830 (Athens: University of Georgia Press, 1994). Also see Peter Charles 
separate codes, those codes could not be "repugnant" - contradictory-to English law. They had to conform to it. Such conformity was increasingly enforced in an expanding network of royal colonies, within which all laws had to be approved by royal governors with strict instructions from the king, Privy Council, and other government oversight bodies such as the Council on Jamaica (in the 1660s), the Council on Foreign Plantations, and later the Board of Trade. So too were all court decisions accountable to English justice: they could be appealed up through the high courts in each colony to the Privy Council. Colonial cases could also be appealed directly to English chancery and common law courts. ${ }^{7}$ Colonies could create their own laws only within limits. We should see their relationship to the imperial state as being similar to the later situation between states and the federal government in the United States. The language of judicial review that is still used in the United States today, that state laws and court decisions cannot be repugnant to federal law or the Supreme Court, was already the norm in the seventeenth century. Colonial slave law emerged within an imperial legal system. ${ }^{8}$

Most scholars have focused discussion of the law of slavery in England on a famous case from the next century, the Somerset case of 1772. They

Hoffer, Law and People in Colonial America (Baltimore: Johns Hopkins University Press, 2019).

7. See, for example, Mary Sarah Bilder, The Transatlantic Constitution: Colonial Legal Culture and the Empire (Cambridge, MA: Harvard University Press, 2004); and Linda Sturtz, Within Her Power: Propertied Women in Colonial Virginia (New York: Routledge, 2002). Hulsebosch sees the colonies as more distinct, particularly on the question of slavery. Hulsebosch, Constituting Empire. While the normal course of appeal of colonial cases was the King's Privy Council, as shown by Bilder and Sturtz, for example, it does not seem uncommon to appeal to the Common Law courts as is shown in many of the cases addressed below. These appeals were analyzed and published by Joseph Henry Smith, Appeals to the Privy Council from the American Plantations (New York: Columbia University Press, 1950). A database that includes such records is Sharon Hamby O'Connor and Mary Sarah Bilder, https://amesfoundation.law.harvard.edu/ColonialAppeals/. On cases being appealed from the colonies to chancery and common law courts, see, for example, my notes on the manuscripts of Lord Chancellor Peter King's rulings (among the Francis Hargrave papers at the British Library) of a case involving dower rights over slaves, appealed from St. Kitts. Susanna Cole's petition (20 December 1727), British Library, Hargrave MS 341, pp. 152-157.

8. Smith, Appeals to the Privy Council from the American Plantations; and Bilder, The Transatlantic Constitution; Lauren Benton has a fine analysis of the importance of Bilder's argument and how it fits with earlier scholarship in "Constitutions and Empires," Law \& Social Inquiry 31 (2006): 177-98. On the centrality of the concept of repugnancy to the power of the Supreme Court today, see Keith E. Whittington, Repugnant Laws: Judicial Review of Acts of Congress from the Founding to the Present (Lawrence: University Press of Kansas, 2019). 
argue that before 1772, "real" slavery didn't exist in England, which remained "free," but only a "slavish servitude." I argue here that such real slavery did exist, and that the Somerset case therefore attempted to overturn the common law of slavery in England itself. By doing so, it implicitly challenged slavery not only in England itself but also across the British Empire.

The common law of England was not wholly distinct from the Civil Law systems on the continent. Henri de Bracton - the font of the common law in the thirteenth century - was deeply influenced by Roman law, and it shaped English common law of what would later be called "villenage," or feudalism. Leading works on the common law published in the early seventeenth century that included substantial sections on feudalism included Bracton's, and Edward Coke's transcription, translation, and gloss upon Thomas Littleton's fifteenth-century treatise in Institutes of the Lawes of England in 1628. Coke upon Littleton was, the most important legal text of the seventeenth century across the empire, and the core of the printed common law. Throughout the seventeenth century, as shown by Spelman's Reliquae among many texts, the common law continued to be in conversation with that older Roman and contemporary civil law legacy from the Catholic church, Spain, Portugal, Holland and France. ${ }^{9}$

By using the courts to approximate an imperial slave code, however, Charles II used a blunt and clumsy instrument to adjust a delicate system of justice according to which colonial law too had to operate. They created a system in which people could be more completely property under the common law than under the civil law of other empires. Instead of creating

9. Henry Spelman, Reliquiae Spelmannianae (London: Black Swan, 1698), although his manuscripts circulated earlier. He was a crucial to the writing of colonial charters in the 1620 s and possibly earlier, a subject I explore in depth elsewhere. Other civil law influences included Hugo Grotius (who by some accounts, was a regular at James I's dining table). Two civilian lawyers helped to shape England's debate over colonization (one of whom, Alberico Gentili, taught as Regius Professor at Oxford), who built on the arguments of Francisco Vitoria, Jean Bodin, and many others. On Gentili and Vittoria, see Christopher L. Tomlins, Freedom Bound: Law, Labor, and Civic Identity in English America (Cambridge: Cambridge University Press, 2010), especially ch. 3; also see Pocock and Davis. Dana Rabin, among others, has treated the question of how villenage was debated in English law with respect to slavery. See J. G. A. Pocock, The Ancient Constitution and the Feudal Law: A Study of English Historical Thought in the Seventeenth Century (Cambridge: Cambridge University Press, 1987); Kathleen Davis, Periodization and Sovereignty: How Ideas of Feudalism and Secularization Govern the Politics of Time (Philadelphia: University of Pennsylvania Press, 2008); and Dana Y. Rabin, “'In a Country of Liberty?': Slavery, Villeinage, and the Making of Whiteness in the Somerset Case (1772)," in Britain and Its Internal Others, 1750-1800 (Manchester: Manchester University Press, 2017), 73-107. 
what was in effect a "caste" system as in India or early modern Spanish America, which recognized the humanity of those on the lowest rung, the English crown relied on justices to bluntly rule that people were property.

The problem was that to function over months and years, beyond a simple system or piracy enforced by the sword alone, slavery needed legitimacy. Before 1677, Governors and councils and sometimes elected legislatures in England's colonies legitimated elements of slavery, but, as we shall see, they were limited to following and manipulating feudal law or master/servant law, both of which had a variety of protections for the villein or servant which imposed limits on ownership. Only after the high court cases from the 1670s and 1680s did English law provide the regulatory structure of markets that made slavery, as it existed in eighteenthand nineteenth-century America, possible.

Charles and James II's judges legitimated slavery both in England and its colonies with the same kind of arguments that they used to justify the king's divine right to rule. Hereditary slavery and hereditary monarchy were logically connected if not conceptually inseparable in the pulpit, where passive obedience to kings and masters was often explicitly connected, and, implicitly, in court cases. So too were the legal principles of the divine right to rule and the idea that heathens and infidels had no rights: they could not be subjects, were aliens, and were outside the protection of any laws. These principles furthermore drew on an existing and powerful set of common law procedures (writs) that protected ownership of things. The judges twisted these legal rationales into a rope that combined feudalism with capitalism, one that defined people as perpetual and hereditary property. They thereby rationalized an exploitative labor system highly compatible with early capitalism; indeed, they created a kind of extreme capitalism, where even people were things, one which would continue, in its basic procedures and writs, into the Antebellum United States.

In the early seventeenth century, Charles I promoted bound labor in his empire, attempting thereby to follow Spain's and Portugal's successful model. He issued royal proclamations in Virginia that gave land to masters for importing servants, and with proprietary grants and charters that promoted similar policies. English colonies in the New World, especially Barbados and other Caribbean colonies, were sometimes buying and selling human beings under particular conditions, from the $1610 \mathrm{~s}$ - not only Africans, but English and Irish - and trying to legally enforce the sales. But such enforcement was problematic, and none of the existing models 
reliably enforced contracts over the sale of people who had not bound themselves (who had not consented).

The system of indentured servitude that brought servants from England, some willingly, others not, manipulated apprenticeship and labor norms to introduce the principle of sale, and this distinguished indentured servitude in the New World from apprenticeship and labor contracts in the old. The idea was that servants for the New World bound themselves to the ship owner, and then the ship owner transferred ownership by sale once in Virginia or Barbados. Those sentenced for crimes were sold by the king to ship owners, with a contract stating that they could be transferred. Laborers also willingly bound themselves, as in this example from Barbados in 1641, which followed the English statute of artificers (laborers) from 1603: "Mathew Field $\mathrm{B}[$ arba]dos laborer covenant to serve Hugh Wackfield. . . 1 whole year. . . . shall truely and faithfully behave himself as a covenanted or indented servant. To pay $600 \mathrm{lbs}$ tob[acc]o or goods $1 / 2$ midsummer next and $1 / 2$ at expiration 31 Dec 1642."10

Children younger than 16 years of age, and generally between the ages of 8 and 16, could, according to England's labor laws, be bound unwillingly; these laws allowed children to be forced into apprenticeships for terms of years (not exceeding age 24 ) in order to learn a trade. ${ }^{11}$ Such contracts fit roughly within apprenticeship norms, which limited the terms of service by law, and arguably the treatment of such servants as well as their resale, depending on the colony and the period. Also, the forced removal of servants was increasingly becoming an issue in England, where kidnapping was widespread in the seventeenth century. In Virginia and Barbados, for example, children who came without contracts, and thus with no indication that they had consented to labor, were sold for terms depending on their adjudged age, but it was not clear that they could then be resold. ${ }^{12}$

10. Barbados deeds, RB 3/1 pp 344-345. I thank Lorena Walsh for sharing her transcriptions.

11. See for example, Holly Brewer, By Birth or Consent: Children, Law, and the Anglo-American Revolution in Authority (Chapel Hill: UNC Press, 2005), esp. 230-287.

12. Brewer, "Age of Reason?" in Chris Tomlins and Bruce Mann, Many Legalities of Early America, on the practice of kidnapping and the legality of transfer of contracts. At the early Chesapeake conference in November 2009, J. Elliot Russo explained how we undercount the number of servants in early eighteenth-century Maryland, because wills did not try to convey indentured servants, but did convey slaves. Her point about undercounting reveals at the same time how fundamental the issue of who could be bought (and sold) and resold was. What was at stake was the nature of the property ownership and the boundedness of the labor obligation. Russo, "The Chesapeake's Invisible People?: Labor Resources of Small Planters in Early Eighteenth Century Maryland and Virginia", unpublished paper. 
While some Englishmen clearly opposed enslaving non-Christians as then practiced in other empires, others likewise supported it; Charles I certainly began to appoint governors and proprietors who did so. But setting up legal processes to support such ownership would prove to be difficult. Between 1620 and 1660, English courts began to allow limited ownership claims that accorded with supposedly ancient laws of villenage. I note supposedly, because under Charles I, lawyers such as Henry Spelman (who was writing colonial charters), were repurposing and reinterpreting English medieval law to suit absolutist ideals as well as expansion. ${ }^{13}$ Villeins could have two statuses: villeins "regardant to a manor," or attached to land, or "villeins en grosse," with a somewhat portable status. According to legal treatises reprinted in the early sixteenth century, villeins had some rights (to initiate complaints against their lords for mistreatment, for example) and the law did not allow for their sale, except in the case of "villeins regardant to a manor," who could be sold with the land. ${ }^{14}$

Figuring out how to adapt legal claims, with some basis in ancient English common law, so as to approximate the legal processes of other empires, was not simple, however. The Civil Law of other European empires such as Spain, Portugal, France, and Holland were complex on questions of slavery, but followed Roman law from Justinian and papal decrees. Such codes lay behind royal proclamations, and then details were negotiated on the ground. Still, slavery was complex in the Spanish Empire. There were many ways in which the souls and rights of the enslaved were legally recognized in, for example, seventeenth-century Spanish colonies such as Peru and Cuba. ${ }^{15}$

The English strategy was to repurpose and rewrite feudal law. In Barbados in 1636, Governor Henry Hawley simply declared that from then on, Africans and Indians who arrived "without contracts" would

13. For the argument that actual feudalism was a myth created by later scholars, see Susan Reynolds, Fiefs and Vassals: The Medieval Evidence Reinterpreted (Oxford: Clarendon Press, 1996); Pocock, The Ancient Constitution and the Feudal Law. Pocock links the origins of the word "feudal" to Henry Spelman. Kathleen Davis situates with Spelman, see especially, Davis, Periodization and Sovereignty, ch. 2.

14. By far the most extensive discussion in all legal treatises, however, was of Villeins regardant, or attached to land. See Coke upon Littleton (the first volume of Coke's Institutes), e.g. one short paragraph on p. $120 \mathrm{~b}$ (verso) is the only mention of villeins en grosse; villeins regardant are discussed on pp. 116-141 (both sides) or for more than 30 pages. My edition is the 11th edition (London: Eliz. Nutt \& R. Gosling, 1719).

15. On Peru, see Michele McKinley's Fractional Freedoms; on Cuba, see Alejandro de la Fuentes and Ariela Gross, Becoming Free, Becoming Black: Race, Freedom, and Law in Cuba, Virginia, and Louisiana (New York: Cambridge University Press, 2020). 
serve for life, a position that fit with feudal law then being republished and reprinted in texts such as Coke upon Littleton in 1628: the logic seemed to be that non-Christians could be considered villeins, as will be explored in more depth, below. Likewise in the case of Bell v. Providence Island in 1639, for example, it appears that Charles I and his Privy Council were seeking to create a neo-feudal law of persons, not only in the empire but also at home. In that case, the former Governor of Providence Island, Philip Bell, sued the Providence Island Company for permanent possession of servants (including "negroes"); the verdict held that people were attached to land, not individuals, but that, since Bell had already departed Providence Island, the proprietary company was owed him compensation for the number of servants that he should have had as governor, in the form of a pension. The king directed the case to the Lord Keeper who presided over the court of Star Chamber: the king subsequently agreed to appoint Bell as governor of Barbados in 1641. ${ }^{16}$

Despite such legal precedents, the selling of those captured and enslaved without their consent in Africa or from Portuguese or Dutch ships, or from the mainland of South or Central America, remained legally problematic in England and its colonies in one important sense: it was difficult to enforce contracts over the sale of a person. English law did allow the exchange of goods on market days, without contracts. According to "Conveyancing Manuals" from the sixteenth and early seventeenth centuries, such "open market" sales were acceptable bargains that required no contract. However, it was difficult to litigate the sale of the "negro," "Indian," or Christian servant who had no contract or even to prove ownership. So if "negroes" or "Christians" without contracts were sold on market days, the merchant who sold them could accept only what goods or money the potential buyer had in hand. The person sold could not be recovered, and indeed was also legally difficult to recover if they ran away to a different master, as there was no easy legal mechanism to litigate ownership. ${ }^{17}$ Because those so "sold" had not signed a contract, they were not covered by English labor law. Feudal law, as explored more below, had no viable

16. See esp. Providence Island Records, TNR CO 124/2 344-5, 348-9 (November 1638, February 1638/9). The case is mentioned by Kupperman, Providence Island, but she did not seem to realize that the Lord Keeper was head of Star Chamber and that the King appointing him to adjudicate was such a significant act. Charles I routinely approved all governors, including Bell as Governor of Providence Island.

17. John Perkins, A Profitable Booke. Treating of the Lawes of England (London: Stationers Company, 1621) [in law French], 1642; later translated into English and retitled; A Treatise of the Laws of England in the Various Branches of Conveyancing, was in the 14th ed. by 1757 (London: Henry, Lintot, 1757), and was one of the most popular guides to conveyancing. See esp. the section on "exchange," e.g., paras 244-258 (it is not paginated). 
mechanisms to litigate ownership. It was not clear how ownership could be protected, or how courts could force the return of people to prior owners when neither side had an enforceable deed.

In Barbados between 1635 and 1675, sellers fudged the issue in two ways: First, when privateers or merchants arrived with stolen "negroes," they usually sold them for goods exchanged on the spot in an open market exchange, thereby skirting the need for (unenforceable) contracts. ${ }^{18}$ Then their new "owners" claimed the "negroes" as feudal tenants or villeins, who were attached to the land. Existing contracts for sales of people in early Barbados, which date from the 1640 s, were not for people themselves, but for estates with people attached, following the 1639 Bell decision. Most deeds involved the sale of people once they were on the island and "attached" to estates. Such a deed from September 1638 conveyed both acreage and English servants: "Edward Seede Gent to William Carter Gentleman my plantation, St James, 100 acres lately purchased of Captain Edmond Reede Esquire, abutting Falter's River, 9 men servants which shall have 2 compleat years to serve to Carter after $4^{\text {th }}$ day next ensuing, all turkeys, poultrie, swyne, working tooles and other utensils." 19 Five years later in 1643, a typical deed might include some "negroes" as well as "servants": "Capt Gerard Hawtaine Gent for 12,800 lbs cotton mortgages to Jonathan Hawtaine Gent deposit 124 acres in St George with present crop, 2 negroes, 4 English servantsHumphrey Bargess, Philip Salmon, Peter Beuchamps, James Goodchild, 2 mares with colt, 1 assnegoe, 1 horse colt, stock of 1 boar, 10 breeedinge sowes with their increase. ${ }^{20}$ In the same year, Alexander Lindsay sold 60 acres near St. John's church along with "2 English servants with times to serve, 4 negroes" as well as four goats, two cows, "hoggs, dunghill fowles, all provisions," including "all the tobacco in the field and all necessaries." 21 Selling people as part of estates, whether Christian "servants" or "negroes," had become normal; in doing so they were following a reconstructed feudal law.

But problems remained in terms of enforcing initial sales. Legal creativity was fine for privateers who had raided Portuguese ships or Spanish colonies and had paid little for their human cargo. They would take whatever was given them, as in the "victuals" given in exchange for the Africans in Virginia in 1619. In such cases, ship captains had invested little in their

18. Perkins, Conveyancing, e.g., paras 92, 258.

19. Abbreviations spelled out and spelling slightly modernized. Barbados Deeds, RB 3-1, $184-85$.

20. Barbados Deeds, RB 3-1, 299-300.

21. June 12, 1643, RB 3-1, 337-38. Lindsay to Francis Dickinson and Robert Haynes for $25,000 \mathrm{lbs}$ of cotton. 
human cargo. They profited mainly from the gold, silver, and other merchandise that they pirated. A smattering of contracts in the 1640s involve complex promises such as this one from September 1642, whereby William Powery promised to pay 6,000 pounds of cotton to Thomas Reve if he should bring him four "negroes" who would serve for their lives: "Thomas Reve Gent in consideration of 2 negroes deliverd by William Powrey Esq and 2 negroes to be delivered within 10 days after arrival of the next ship bringing negroes to be sould off [on] this island to serve Thomas or assignes during their lives and for $6,000 \mathrm{lbs}$ cleare cotton to be paid-3,000 lbs 1 May next and 3,000 1 June." If he did not have the 6,000 pounds of cotton he would forfeit his house and 12 acres "near Indian Bridge and household goods" including " 2 chairs, 12 stooles, 1 court cubbard, 2 tables and frames, 1 tester and backe for a bedstead, 2 cows, 3 doz connyes [rabbits] and a bucke." ${ }^{22}$

Another attempt in the 1640 s created pre-contracts for the sale of "negroes" that involved planters mortgaging their goods and estates: George Richardson and Richard Barr, two English merchants arrived in Barbados in July 1644 with forty-seven Africans. They sold twenty-three of them for "ready goods" and took elaborate bonds for the other twentyfour, by which the buyers promised next spring and summer's harvests of tobacco and cotton. In case the buyers defaulted in delivering the harvest on time, elaborate bonds from the purchasers mortgaged not only the "negroes" that they had sold to them on credit, but additional collateral. So Edward Croste and Jonias Hart received " 8 negroes" but if they did not have the 5,600 pounds of cotton and 11,200 pounds of tobacco they promised by April 30, they would forfeit " 5 negroes and 3 servants for terms and also [the] 8 negores" they had purchased. ${ }^{23}$ It is not clear that they could have enforced such contracts. The two merchants also took orders for about 100 "sound negroes" that they would deliver the next summer, with each purchaser, in turn, mortgaging their estates for future payment. The purchasers had no choices over whom they were buying, in terms of age or sex. After that wrangling, it does not seem that they returned with their promised human cargo. Overall, Barbados deed books show that pre-contracting was rare in the 1640s. All of this negotiating, whether promises of pre-payment, post-payment, or ready goods, or mortgaging entire estates, revealed methods of exchange and financing that risked much on both sides, with many levels of insecurity. ${ }^{24}$

22. RB 3-1, 132-34.

23. RB 3-1, 419, dated 31 July, 1644.

24. RB 3-1, 419-39. 
When Charles II was restored to his throne in 1660, he took dramatic steps to expand and support bound labor throughout his empire as well as the slave trade, no doubt in part because he had lost sources of revenue that his father had enjoyed, such as that from the court of wards and many royal estates. Instead, Parliament granted him increased revenues in the form of import taxes: customs on goods produced in the colonies, especially enumerated goods such as tobacco and sugar, excise taxes on select goods produced in other countries. The result was that Charles II had every impetus to expand colonial production of staple crops, and thereby the large estates and bound labor which produced them. Charles II made immediate efforts to get England much more involved in the slave trade and the export of indentured servants, and to regularize and systematize policies toward the status of both. Charles II set up the RAC and used the Royal Navy (and his marriage) to expand English claims to Africa and England's control over forts that enabled the slave trade. He held the first meeting for the "Company of Royal Adventurers into Africa" beginning in October of 1660, and then set up a committee to oversee colonial policy, with some forty-eight members, in December. He gave the committee instructions to regularize laws in all colonies, including those with respect to servants (including "negro servants"). He promoted officials at home and in the colonies who reflected such views. ${ }^{25}$

While Barbados' piecemeal and improvised claims of ownership adhered roughly to English feudal or labor law, they proved inadequate for the RAC. It was one thing for a privateer to exchange a cargo of "negroes" or "Indians" for the cotton, tobacco, or sugar at hand when such human cargo had been literally stolen from nearby Spanish or Portuguese ships or plantations. Privateers did not have a large investment in their human cargo. It was quite another when that cargo was purchased and shipped from Africa, as was the case with the RAC, and involved a significant investment.

The captains of company ships who arrived with valuable and highly perishable cargoes of humans were in an especially difficult situation

25. Holly Brewer, "Slavery, Sovereignty, and 'Inheritable Blood': Reconsidering John Locke and the Origins of American Slavery," The American Historical Review 122 (2017): 1038-78; Abigail L. Swingen, Competing Visions of Empire: Labor, Slavery, and the Origins of the British Atlantic Empire (New Haven: Yale University Press, 2015). "Commission to Edw. Hyde, Lord Chancellor, Thos. Earl of Southampton, Lord Treasurer, Edw. Earl of Manchester, Lord Chamberlain, Theop. Earl of Lincoln, John Earl of Clare, Jas. Earl of Marlborough, \& etc." TNA CO 1/14, No. 59, CO 1/33, No. 81. Westminster. Dec 1, 1660-1664. The entries for January and February 1661, for example, refer variously to servants as "Conditionall Servants" versus "Blacks" on one page and to "slaves" who needed converstion to Christianity in another, pp. 102a-b. 
when planters had insufficient crops to exchange. If they arrived after another merchant had bought up the planters' sugar, tobacco, cotton, or indigo, or if they arrived before crops were harvested, for example, captains faced the prospect of having to linger while the people they had on board sickened or died. They had to feed them as well: by 1667 the African Company claimed that many had died while in the hands of the factors (sales representatives for the RAC), awaiting planters who could purchase them outright. In the 1660s they increasingly accepted notes of hand (promissory notes) but then found that those notes were nearly impossible to enforce. Ellis Leighton, the Company's secretary, acknowledged in a 1667 pamphlet that while the Company's bankruptcy situation was partly due to losses incurred during the Anglo-Dutch war, the main problem was their inability to collect debts from planters. The depredations of DeRuyter in Africa when he attacked English ships and castles were costly, but "these Losses could not have sunk the Companies Credit, had the Planters and Merchants, especially those of Barbados, complied with their obligations, who owed the company $£ 90,000$, of which they of Barbados owe $£ 60,000$." Their dire financial straits were due mostly to the unpaid debts of planters. ${ }^{26}$

Even as they were unable to collect from their debtors, the company's expenses were multiplying. They faced not only losses from their efforts to wrest control of the African forts (and the consequent wars with the Dutch) but necessary expenses for fortifying the castles on the African coast that enabled the trade as well as protecting such ships on the seas. Despite royal subsidies, they were reaching a point of financial crisis. As the Company summarized: "That without Forts and force by Land and Sea, [the trade in "Negroes"] cannot be secured to this Kingdom. That without the Royal Authority, and a Joynt Stock, those Forts and Forces cannot be supported. ${ }^{, 27}$ Leighton was correct. As voyages like that of Prince Rupert in 1651 had shown, without forts and alliances, the slave trade was dangerous and unprofitable: after a raid on a village he had captured only a young boy, but meanwhile had lost a skilled African sailor (who had fled), and several sailors had died. The forts were necessary to the trade, and the war to obtain and then protect them was costing the company dearly. ${ }^{28}$

26. Answer of the Company of Royal Adventurers of England trading into Africa (London, n.p. 1667).

27. Ibid., 17-18.

28. The best published sources on Rupert's voyage lead back to a manuscript that has only been partly transcribed. See Patrick Morrah, Prince Rupert of the Rhine (London, 1976), Book 2, chapter 4, "In Western Seas," and James Cleugh, Prince Rupert: A Biography (London, 1934), 208. The original manuscript (as of 1976) was in the Wiltshire County Archives, "Rupert Sea Narrative." It was partly transcribed by Eliot Warburton, Memoirs 
Litigating the sales of people became an increasingly pressing question as the taxes from sugar and tobacco produced by bound laborers flowed into imperial coffers. But colonies were not permitted to make laws "repugnant" to those of England, a point that was nothing short of an obsession to Charles II's imperial authorities. His Council on Foreign Plantations during the 1660 s was to ensure that colonies followed English law, and failure to do so could lead to the revocation of a colony's charter of governance and to more personal political repercussions. ${ }^{29}$

Forced labor for a period of years as a punishment for a crime could be justified - it had even been practiced by Cromwell. Kidnapping poor children from the streets of London and Bristol to serve the owners of the large land grants that the king was handing out could be legalized under the old poor law, which allowed the binding of poor children. Children and underemployed adults - "vagrants" - could be bound to labor for a term of years with arguments that it was for their own good, a kind of contorted and coerced apprenticeship. ${ }^{30}$ But how does one make perpetual and hereditary servitude legal, especially in England itself, with its entrenched system of laws?

The attention of crown officials began to focus on the legal difficulties of securing human property. In 1663, Humphrey Walrond lost his position as governor of Barbados over exactly that question. Walrond refused to force

of Prince Rupert and the Cavaliers: Including Their Private Correspondence, Now First Published from the Original Manuscripts. In Three Volumes (Rich. Bentley, 1849).

29. See manuscript of Charles II's instructions to the new committee, which also contains 64 pages of notes on their meetings over the next several years. It is interesting that the letter in which the issue of "repugnancy" comes up most explicitly is the letter to the New England colonies, see esp. manuscript December 1, 1660, 24-26, The National Archives (hereafter TNA) CO 1/14, No. 59, CO 1/33, No. 81, Calendar of State Papers, Colonial CSPC Item 2698, 1:492-93, which contains a brief summary. I have found dozens of other such orders; every law reviewed by the Council on Foreign Plantations and Charles II's privy council had to meet this test.

30. On providing servants for the plantations from among the "noxious and unprofitable" and those who could be persuaded to go, see Charles II's Instructions to the Council on Foreign plantations, December 1, 1660, TNA Catalogue Reference: CO 1/14, No. 59, CO $1 / 33$, No. 81. "You are to take into your consideration how our severall Plantations may be best supplied with servants that neither our Collonies ispecially such as our immediately under our Commissions may be unprovided in so essentiall an assistance nor any of our good Subjects may be forced or enticed away by any unlawfull or indirect way. And that such as are willing to be transported thither to seek better fortunes thin they can meete with at home may be encouraged thereunto. And how such a course may be legally settled for the future. That Vagraunts and others who remaine here noxious \& unprofitable may be so transplanted to the generall advantage of the publique as well as the particular commodities of our fforraigne Plantations." On this question more generally see, for example Tomlins, Freedom Bound. 
the sale of estates promised as collateral for planters' debts to the RAC. Technically, the new proprietor of Barbados, Francis Willoughby, removed him for failing to transfer to the king some of the taxes he had collected on the sale of "negroes" to the Spanish, but letters to and from the crown immediately before his dismissal were concerned mostly with Walrond's failure to enforce the collection of debts for slave sales by merchants. Walrond was instead imprisoning merchants who tried to collect the debts they were owed by "attaching" (or legally confiscating) the estates and goods of their creditors: "Merchants who had obtained attachments were imprisoned for refusing to return goods in their possession." Why had Walrond done so? As the Council on Foreign Plantations informed the king in May of 1663, the Council "are of opinion that the President and Council issued the order as well to avoid paying their own debts." All was chaos, as even the factors were refusing to render their accounts. As the Council concluded: "Merchants, owners, and masters of ships are greatly disheartened by this stop of justice. The order is without precedent, and of so evil consequence that if not immediately prevented it will be the ruin not only of Barbadoes, but of all other plantations in America." Then they issued strong instructions if the king wanted to prevent the chaos from spreading he had to enforce the repayment of debts. "His Majesty is advised to reverse said order, and to forbid the like in future under severe penalties; to permit merchants and others who have suffered, to take their legal remedy against the makers of said order, that they be removed from their present employment, and such further directions given for quickening legal proceedings in Barbadoes and other Plantations as may be deemed necessary." 31

After Walrond was deposed for not "quickening legal proceedings" that the crown "deemed necessary" for the collection of debts, the next governor, Francis Willoughby, issued a draconian proclamation, at the crown's insistence, that allowed the confiscation of entire estates by fire sale for non-payment of debts. But this, too, proved unworkable. Local judges,

31. TNA CO 1/17, No. 35, June 5, 1663, "Report of the Council for Foreign Plantations to the King, concerning an Order made by the Deputy Governor of Barbados." Also see CSPC 5:137. Modyford, then a factor for the royal African Company, was the one who reported Governor Walrond to the crown for taxing the sale of African slaves to the Spanish without obtaining the consent of the crown, especially since Walrond had levied the tax on the Royal African Company and the Duke of York. "A ship belonging to the Royal African Company sold negroes to the Spaniards, and although . . . they were the duke of York's, he [Governor Walrond] insolently enforced the payment of 11 pieces of eight" per head (the Spanish were paying between 125 to 140 pieces of eight per head, so this was a tax of almost $10 \%$ ). This letter was annexed to reports from Whitehall of the Council on Foreign plantations dated February 26, 1663, TNA CO 1/17, 7, 8, 9, CPSC 5: 123-24. 
who knew the details, would fail to announce such sales and then purchase the entire estate themselves, including all servants and slaves, for not only a fraction of their worth but also for a fraction of the debt owed. ${ }^{32}$ Part of the problem was, as one RAC official summarized: "the Planters (our Debtors) are Judges" in the courts of law meant that the judges had little incentive to cooperate. $^{33}$

Despite such harsh legislation between 1664 and 1677 either pushed through the legislature or proclaimed the king's governors, the efforts largely failed. The draconian solutions only exposed a hopelessly inadequate credit system when it came to the purchases of enslaved Black men, women, and children. The company tried to designate local factors who would help to sell fragile human cargoes, keep them until sales could be arranged, and keep track of and prosecute debts. But even this strategy did not work well. These Factors were costly, had multiple tasks, and had difficulty collecting debts despite extensive royal support. Thomas Modyford was a factor for the RAC in Barbados, earning a large retainer of $£ 300$ per annum in 1663 . But he, and a cycle of others, seemed to simply accumulate more notes, most of which were bad. So in 1671, John Reid reported to Lord Arlington that, since he had become the RAC's factor in Barbados in 1667, he had tried in vain to collect debts, with little success even 4 years later. His failures had left his own credit in ruins. "The Royal Companies business . . . hast almost undone me for I having come in on a parcell of ould and bad debts have almost lost that credit I had from them because I cannot recover the said debts." ${ }^{34}$ Failure to collect paper debts - unofficial contracts over the sale of people that could not be legally enforced-led to the RAC's financial collapse in $1667 .^{35}$

By 1671 the RAC would be completely bankrupt and forced through a major resettlement almost solely because they could not force planters in Barbados to pay for their "slaves": they could be prosecuted but the enslaved human collateral could not be recovered. As factors for the RAC acknowledged in 1664, it was exceedingly difficult to collect these unsecured debts, and attempts to force sale often led to goods being overestimated in value, and creditors then had to pay the difference. By the end

32. For Charles II's order (made in Privy Council), see Privy Council Register Charles II, 8:294 (May 12, 1669); also Zook, Company of Royal Adventurers, 81. For examples of how this order led to new problems for creditors, see Barbados council and assembly records from Barbados archives (my notes on paper).

33. Answer of the Company of Royal Adventurers of England trading into Africa.

34. August 2, 1671, TNA CO 1/27, No. 13, 1 .

35. On the terms of the bankruptcy and refinance, see Zook, Company of Royal Adventurers, ch. 4; Kenneth Gordon Davies, Royal African Company (London: Longmans, Green, 1957), esp. 57-59. 
of 1665 , Barbados planters owed the RAC more than $£ 40,000$, and by 1667 , Barbados planters owed $£ 60,000$. By 1668 , the company owed more than $£ 58,000$ to creditors in England and could not afford to pay for the protection and upkeep of their forts in Africa: they begged for more military aid from the crown and issued a short-term lease to the Gambia company to pay rent and cover their basic expenses. In 1671, with the king's permission, they dissolved the old company, paying their creditors only $30-40 \%$ of the face value. The king obligingly offered them a new charter; many of the new investors simply transferred their shares from the old, and James, Duke of York, the king's brother, remained its presiding officer. ${ }^{36}$

The new RAC refused to import any more Africans without advance payment from planters. In 1672, James issued a proclamation that tried to solve the problem by universalizing pre-payment. The proclamation was printed and widely circulated in the colonies and at home, with James's name prominently displayed next to a price list for "negroes" that varied only by where they were sold. Any planter who wanted a "negro servant" had to pre-pay on the Royal Exchange in London for any that they wanted from Africa. The exchange set prices and stated that the RAC might import a few extras but would not from that point forward import any "negro servant" unless the buyer had pre-paid. ${ }^{37}$ Pre-payment requirements were onerous, with delays of months or years as the money and orders were sent by ship from the colonies to London and then to Africa and back to the colonies. Without credit, and given the prohibitive price of slaves, many planters could not afford to buy them. They also had no choice over whom they purchased, men or women, adult or child, old or young, sick or well. It was not a viable system. The lack of credit and high prices are part of why slavery did not "take off' in the Chesapeake during the 1660 s and early 1670 s. ${ }^{38}$

36. Zook, Company of Royal Adventurers, 26. The company's creditors accepted $40 \%$ because otherwise, with the new charter, they might get nothing.

37. On problems with credit, see Jacob C. Price, "Credit in the Slave Trade and Plantation Economies," in Slavery and the Rise of the Atlantic System, ed. Barbara L. Slow (Cambridge: Cambridge University Press, 1991), 293-339; Zook, The Company of Royal Adventurers Trading into Africa, ch. 4.

38. At that point, they were still called the "Royal Adventurers into Africa," which existed between 1660 and 1672. Indeed part of the reason that they reformed under a new name in 1672 was in order to consolidate their debts and refinance. In addition to Price, "Credit in the Slave Trade," see Zook, The Company of Royal Adventurers Trading into Africa, and David W. Galenson, "Economic Aspects of the Growth of Slavery in the Seventeenth-Century Chesapeake," in Solow, ed., Slavery and the Rise of the Atlantic System, 265-92, especially 266-69. 
The RAC delivered some slaves to their various colonies in 1673-75 as a consequence of the pre-payment requirement. But not only was it onerous: while pre-payment protected the RAC's investments, it left planters wildly exposed. The problems with enforcing contracts still existed but now, the planters were unable to enforce claims for old, ill, or undelivered cargos. James Duke of York's proclamation therefore did little to solve the underlying problem.

$* * *$

Into this crisis stepped Parliament, whose members made two attempts to solve the problem of the legality of sale and the security of property by clearly defining non-Christians (not English subjects) as legally enslaveable. Despite the fact that the "cavalier parliament" largely supported the king, neither passed, a fact that suggests substantial opposition to slavery in both houses. The first proposed law, which originated in the House of Commons in the 1660s, sought to transfer Spanish slave law wholesale to England and its colonies. It declared that "Negroes \& Infidells" who are "daily brought unto the severall English plantations," even if baptized, "shall \& may Continue bond men \& bond womoen unto [their masters] during their Naturall lives, according to the order and practice of other Christian Governments," such as the Spanish and Portuguese. Next, in 1674, a member of the House of Lords tried to legalize slavery in England and its empire by adding a clause to a bill on masters and servants that had originated in the House of Commons. The (anonymous) lord suggested a clause defining in "what Manner, and upon what terms, Slaves, either Blacks or any other Foreigners, not being Christians may be used in England." The key elements of both proposals held that "foreigners" or non-"Christians" could be "used" as "slaves," in both England and the colonies. ${ }^{39}$

Parliamentary laws would have automatically enabled other laws throughout the empire because it would have changed the scope of what was repugnant (or not) to English law. But both laws failed to be ratified. (We know little about why since it was then illegal to keep formal records of debates in Parliament.) Charles II could issue a proclamation limiting trade with Africa to the RAC and enforcing their monopoly, as he did in 1674. But creating legal slavery in the empire required something more. ${ }^{40}$

39. Ruth Paley, Cristina Malcolmson, and Michael Hunter, "Parliament and Slavery, 1660-c. 1710," Slavery and Abolition 31 (June 2010): 257-58, and also document one, 260-61, which is the "Tanner ms." from Bodl. MS Tanner, fols 52-53.

40. Ibid. 
Meanwhile, in the view of many Whigs, Charles II had emerged as a tyrant. Some of these same men, including Anthony Ashley Cooper, the first Earl of Shaftesbury and John Locke (Shaftesbury's secretary), had cooperated to varying degrees with Charles II for more than a decade. Shaftesbury had been Lord Chancellor (1669-72) and briefly assistant director of the RAC. Both had owned RAC shares. But between 1674 and 1675, that cooperation evaporated in the face of Charles II's costly wars for empire, open advocacy of slavery, and effort to repress all dissent, even in Parliament, in the form of a new oath. All members were to swear that they would never raise arms against the king. Nor would they criticize him, even in Parliament. In 1675 they co-authored a pamphlet that included debates in the House of Lords over an oath they saw as enabling Charles II to exercise absolute power; after its publication, it was burned by the common hangman. Locke fled to France. Shaftesbury ended up in the Tower, denied habeus Corpus. ${ }^{41}$

\section{***}

Unable to get an imperial slave code through Parliament, Charles II turned to the courts. But he had limited power over the high court until 1676. In 1660, Charles II had originally appointed Sir Mathew Hale, one of the few moderate judges, using a writ that allowed him to serve during "good behavior." So Charles could not merely fire Hale as chief justice in 1674: he had to be impeached. ${ }^{42}$

On the question of slavery, Hale was uncooperative. Hale never presided over a case that recognized slavery as legal in England or its empire. Instead, in a quiet rebuke to crown justifications for slavery, Hale published a treatise on the "origination of man" in which he argued that all peoples around the world have a common parentage. Everyone, including

41. [Locke and Shaftesbury] A Letter from a Gentleman to his Friend in the Country (London, November? 1675); on Locke's flight, see manuscript of power of attorney among his papers, and Locke's letters, which show his location in France.

42. Charles II decided at the Restoration to keep nine out of fifteen judges in the Exchequer and the King's Bench and other courts in office. These nine, appointed under Cromwell, were men recognized as moderates; all of them had been appointed by patents that allowed them to keep their positions during their good behavior. Likewise he kept many of the judges in the Court of Common Pleas, of whom Hale was one. Hale, in particular, had helped to defend Charles II's father, Charles I, early in the Civil Wars. So in 1660, Charles II put Hale in charge of the Exchequer, and promoted him to chief justice of the high court of King's Bench in 1671. For Hales' 1671 appointment, see TNA Patent Rolls C 66/ 3127 (May 28, 1671); Alfred F. Havighurst, "The Judiciary and Politics in the Reign of Charles II," Law Quarterly Review 66 (1950): 62-78, esp. 63-65; Foss, Judges, 9. 
"heathens," have some of God's essence. ${ }^{43}$ Hale argued that even infidels were under God's (and the law's) protection. Although a philosophic work, it was widely read. Morgan Godwyn, a minister in Barbados, for example, used Hale's arguments to argue against planters' justifications for slavery in Barbados. ${ }^{44}$

After Hale's death in February 1676, the king chose a new chief justice who would more readily accede to his wishes: Sir Richard Rainsford. Rainsford had ruled in a 1671 King's Bench case that a town clerk in Stratford upon Avon could be removed without cause, since the town charter allowed him to be hired "durante beneplacito" or "during good pleasure." Thus the mayor could remove him; that is, fire him, "without cause" or "without a crime." 45 And in a controversial move even at the time, Rainsford agreed to assume his post as chief justice on the same conditions: only "durante beneplacito," at the pleasure of the King. Charles II could dismiss him at will, without cause. ${ }^{46}$

Rainsford had a history of supporting the royal side, even during the protectorate. After 1660, he became a fierce prosecutor of religious dissidents. In addition to his multiple (and widely reported) condemnations of Quakers to hard labor for 10 years in Barbados for the crime of attending religious gatherings with more than four people, he was an outspoken opponent of freedom of the press. Finally, he revoked land confiscations made under Cromwell, voiding sales and restoring lands to the families of Charles I's supporters. ${ }^{47}$

After becoming chief justice in April 1676, Rainsford presided over judgments very different from Hale's. In June 1676, after some members of the House of Lords issued a warrant to imprison Shaftesbury in the Tower of London, Rainsford refused Shaftsbury habeus corpus, almost certainly on Charles II's instructions. Shaftesbury spent more than a year

43. Sir Matthew Hale, The Primitive Origination of Mankind: Considered and Examined According to the Light of Nature (London: William Godbid, 1677). It was therefore published posthumously.

44. For Godwyn's discussion of Hale's ideas, see his Negroe's and Indian's Advocate (London, n.p., 1680), 15.

45. "The King against the Mayor, \&c. of Stratford upon Avon," 1 Lev. 292, 83 Eng. Rep. 413 [1671] Trin. 22 Car. II. In B. R.

46. Foss, Judges, 9:3-4; and Morton versus Hopkins \& Spencer Siderfin 1:409; [from Siderfin], translated from the law French: "Note that this term Sir Richard Rainsford, one of the Barons of the Exchequer was made justice of this court by patent, "dur' beneplacito" [during good-pleasure], and it was taken privately in front of the Senior Keeper Bridgman in his chamber."

47. Anon., Another out-cry of the innocent \& oppressed being a true account of the unjust and illegal proceedings of Richard Rainsford (London, n.p., 1665); Foss, Judges, 9:3-4. See "Richard Rainsford" in Oxford Dictionary of National Biography (ODNB). 
in the Tower; the king ordered his release only after he apologized to him personally. Rainsford's agreement to punish the king's critics did intimidate many, but it also helped to solidify opposition. ${ }^{4}$

Rainsford's other crucial judgment - now largely forgotten and when remembered often misunderstood - made slavery legal in England itself as well as in its empire. ${ }^{49} \mathrm{~A}$ few scholars have commented briefly on it -it is increasingly recognized as significant. ${ }^{50} \mathrm{~A}$ complex sequence of events preceded his judgment in that case, Butts v. Penny, events that reveal the multiple dimensions of imperial intervention in slavery and the slave trade.

Butts v. Penny was a court case that began in Barbados and proceeded upward to English common law courts. While technically it did so via a legal fiction that the case began in Middlesex, a suburb of London (a common legal fiction for hearing cases outside of England) it was heard by England's highest court due directly to the crown's effort to provide the slave trade with a stronger legal foundation. It was interactive. Charles II's instructions to Jonathan Atkins when he appointed him governor of Barbados in 1674 had emphasized that he must protect the interests of the RAC and find better means to collect the company's debts for their slave sales. Numerous letters from the king and his Privy Council (and Council on Foreign Plantations) to Atkins over the next several years reiterated these concerns. Atkins described the planters' current tactic for avoiding payment, which involved planters having land in two jurisdictions, and moving their "goods and negroes into the jurisdiction where he is not condemned," so that when the RAC or their factors received a judgment, it was to bare land only.

48. Kenneth Harold Dobson Haley, The First Earl of Shaftesbury (Oxford: Clarendon Press, 1968), esp. chapters 19-22 and pp. 428-430.

49. See, for example, Van Cleve, "Somerset's case and its antecedents." Wiecek, "Somerset: Lord Mansfield and the Legitimacy of Slavery," does realize that the case is important, and foresees that it might have an imperial impact, but does not develop that question. Imtiaz H. Habib, Black Lives in the English Archives, 1500-1677: Imprints of the Invisible (London: Ashgate Publishing, Ltd., 2008), argues that the case was important in England itself, as he notes that the records relating to black lives in England itself suddenly shift, and therefore, he ends his analysis in 1677.

50. See, for example, James Walvin, Black and White: The Negro and English Society, 1555-1945 (London: Penguin Press, 1973); Wiecek, "Somerset: Lord Mansfield and the Legitimacy of Slavery"; A. Leon Higginbotham, In the Matter of Color: Race and the American Legal Process. The Colonial Period (New York: Oxford University Press, 1978); Habib, Black Lives in the English Archives, 1500-1677; Amanda Bailey, Of Bondage: Debt, Property, and Personhood in Early Modern England (Philadelphia: University of Pennsylvania Press, 2013); and Rabin, “'In a Country of Liberty?" 
The complaint of not paying debts in Barbadoes, proceeds from hence. There are five Courts Palatine, having distinct jurisdictions, the island being divided into five cantons or shares, severally depending on the several jurisdictions are courts, so that what is condemned in one court cannot be executed in another jurisdiction, and it frequently falls out that a planter who has lands in two jurisdictions, when one comes to make distress, withdraws his goods and negroes into the jurisdiction where he is not condemned, defrauding thereby his creditors.

To solve this issue, Atkins recommended consolidating the jurisdictional question. But he pointed also to corruption: "The Judges have neither stipends nor fees, and if they get anything it is by favouring the party condemned; they make their own clerks; and the marshals or bailiffs, who are made by the Provost Marshal, for money give notice to the debtor when they will distrain; who makes over his estate beforehand, and purchases some small piece of land in Scotland (as they call it)" on the North part of the island, very windy and not as fertile "which is appraised at some small value, with which the creditor must be content." The only solution, Atkins concluded, for expanding trade were new laws that would enforce debt collection. "Much greater trade requires laws for better support of credit, which is much impaired by not paying their debts." Atkins requested that the king intervene directly to create better credit networks and put slavery on a stronger financial footing. "The King's commands will be needful that they be brought to an account." 51

Atkins' chance came in February 1677, with a new assembly and with pressure from the RAC surrounding Butts v. Penny, then under review by the King's Bench. Planters had by then realized that the slave trade would disappear without serious reform. They also realized that they needed a better system of establishing ownership among themselves.

51. Atkins was a close confidant of James, Duke of York, and had been since he had served under him in France in the 1650s in the French army. Stephen Saunders Webb, "William Blathwayt, Imperial Fixer: Muddling Through to Empire, 1689-1717," The William and Mary Quarterly 26 (1969): 373-415. Also see Sir Jonathan Atkins Commission and Instructions, February 6, 1673/4, TNA CO 1/30, No. 90 CSPC Item 1183, 7:540. The final quotes are from "Sir Jonathan Atkin's proposals concerning some things to be added to his Commission and Instructions," undated but assigned date of December 1673 in the CSPC archives volume 7, pp. 535-544, item 1183. The actual date must be later, since it postdates his arrival in 1674: given other correspondence, he most likely wrote it in 1676. "Atkins to Sir Joseph Williamson," January 22, 1676/7; CO 1/39, No. 9 (p. 2). Barbados, "Transcript Acts," pp. 435-437 (February 20, 1676/7). Almost all of the dozens of letters back and forth between crown officials and Atkins between 1673 and 1677 mention debt, trade, slaves, and the Royal African Company, as do Atkins' explicit instructions from the king, which encouraged him to take especial care of the Royal African Company and promised punishment if he did not do so. 
Such issues arose frequently, not only in the obvious situation of runaways, but also in cases of sale and inheritance. Planters agreed to establish a firmer basis for claiming "slaves" as property; in exchange, Atkins agreed to support a petition from Barbadian planters' to the RAC to bring more slaves. The law in question designated slaves as simple property subject to actions of trespass, what we would call torts today. It thus enabled sellers to recover a slave whom they sold upon credit, by using powerful torts, then called "trespasses" or wrongs. It made enslaved people into a form of credit. Previously, as this 1677 law made clear, many runaways had simply stayed on different estates, with their new masters refusing to return them. The new legal mechanisms allowed by these torts, or writs of trespass (technically they were called trover or detinue, of which, more subsequently) enabled a quick and a simple process - and a punitive one- for restoring and reclaiming ownership.

But simply passing such a law was problematic insofar as these writs of trespass had previously been used to recover things, and sometimes animals, such as a dog or a hawk, but not human beings. And the writs to recover feudal villeins, the only ones that were clearly legal under the common law of either master/servant or villeinage, were both cumbersome and toothless. The latter did not enforce recovery. Furthermore, such feudal writs made it difficult to establish who could claim ownership of another person. Even if "Christians" could claim non-Christians as "slaves," which Christians specifically had such a right, and over whom?

Because these writs applied only to things, Atkins' new Barbados law that allowed people to be claimed as property using writs of trespass, was repugnant to English common law as it then stood. ${ }^{52}$ The solution

52. "An Act for Securing the possession of Negroes and Slaves," February 1677, Barbados, "Transcript Acts," vol. 1, 1650-1682, manuscript in possession of the Barbados Historical society, 436-38. "Whereas the Possession of the Lands in this Island hath been well Secured by the act against Clandestine Entryes, that the possession of Negroes and Slaves may be secured in Like Manner, Be it enacted and Ordained by his Excellency Sir Jonathan Atkins Knight Captain Generall and Chiefe Governor of this and other the Carabee Islands the Councell and Assembly of this Island and by the authority of the same; That noe person after publication of this act take or detaine any Negroe or Slave which hath bin in the possession of another within this island for the space of three moneths together without due course of law upon any pretence whatsoever, upon payne of forfeiting Twenty pounds of Muscovado Sugar to the party grieved for every day that hee shall detayne each Negroe or Slave. . . . That in all Suits for detinue of any (437) Slave or Slaves the Defendant being lawfully Summoned by a Writt or Warrant under the hand and Seale of the Judge . . . And in case Such Detainor or detainors shall refuse or Neglect to appeare at the said first court lawfull summons being proved, the Court shall give Judgment by nihil dicit [nothing to say], and execution forthwith to Issue as aforesaid" (signed by assembly, council and governor February 20, 1676/7). Examination of Dalton's 
to the problem of repugnance was to coordinate. Atkins' law reached England in April 1677 just after England's King's Bench - their highest court's - initial judgment in Butts v. Penny, the court case originated in Barbados the prior summer. It tested whether a person could be considered simple property, whether that person could be sold as goods, and whether traditional mechanisms used for the recovery of debts and damages could be applied to people. England's highest court weighed a principle: could human beings be considered simple property?

The plaintiff, the unfortunately named Thomas Butts, was a naval officer who served in the third Dutch war off the African coast in a ship called the Dover Dogger. The same ship, at the end of the war in 1674, gradually shifted from patrolling the coast (under command of the Navy) into service with the RAC. After several months in Guinea, the Dover Dogger was used to transport eighty-two Africans to Barbados. Nine of them died during the middle passage. As the report noted, the officers of the Dover Dogger "sold them [the "negroes'] at good rates." However "several ships are there, and sugars are very scarce," so most of the ships "will come home dead freighted," or without the sugar that they sought in exchange for slaves. They sold the newly enslaved Africans, therefore, on credit. Butts, one of those officers, helped to sell seventy-three men, women, and children from the Dover Dogger in Barbados on behalf of the RAC, by taking on a personal debt, just as factors for the RAC had done earlier. He then owed part of that debt to the RAC, less his own commission, but needed to collect from planters in Barbados. Butts arrived back in London in July 1676, after spending 28 months aboard the Dover Dogger. In October 1677, after the case was resolved, Charles II would reward Butts for his services by granting him possession of the Dover Dogger, valued at $£ 100 .{ }^{53}$

Countrey Justice (1618), for example, under the topics of "detinue" and "trover," the two most important writs of trespass (what we would today call torts) discuss them only as applying to simple property, such as jewels, silver, curtains. A search of English Reports before 1677 reveals the same thing.

53. The slave voyages Web site, citing Vol. 1 of the Royal African records (TNA T70/ 936), gives the number as seventy-three Africans sold into slavery at Barbados. The report to the Privy Council stated that eighty-two were brought aboard in Guinea, but that six or seven died. Putting these data together, it appears that the number who died on the voyage was nine. Slavevoyages.org lists it as voyage 9687 and estimates its arrival in 1675. In fact it must have arrived in Barbados in April or May 1676, according to a report dated July 27, 1676. See TNA SP 29/384, f 16 item 13. It had before that spent "several months on the coast of Guinea." After Butts v. Penny was finalized, the value of the Dover Dogger was appraised by the Navy commissioners on September 29. Samuel Pepys confirmed to the Admiralty Board in October 1677, after Butts v. Penny was finalized, that "I pursuance of his majesty's resolution" at the Admiralty Table, that "a privy seal should pass for granting 
Thomas Butts's several roles show how institutional roles overlapped during this period: Butts was part Naval officer; part employee of the RAC, and while he sued in his own name, he did so on behalf of the RAC. Given that James, Duke of York, was both the current governor of the RAC, and a former admiral of the Navy, that Butts had worked for James in both respects, and that the king allowed the RAC free use of Royal Navy ships, Butts's several roles are unsurprising. Most interesting is the crown's apparent reluctance to bring suit in the name of the RAC itself. The way that financing worked in this period involved factors who sold and collected debts in their own name, on behalf of the company, so this makes sense. But it also seems a deliberate effort to hide the RAC role at a moment of great political controversy and increasing political opposition to both Charles II and his brother James. The king seems to have rewarded Butts with the Dover Dogger for playing that delicate and controversial role.

The number of Black men, women, and children whom Butts sold in Barbados was only part of the seventy-three. The two reports of the case offered contradictory numbers. One claimed that the case concerned the sale of 100 "negroes," the other 10 "and a half." The "half" seems an error, but instead shows the connections between the Spanish slave trade and England's. The Spanish Asiento calculated slave imports in "piezas de Indias," or "pieces." In those calculations, children, women, the elderly (or the sick) might be measured as only part—one half or three quartersof an able-bodied enslaved man. The report that contained the " $1 / 2$ " was also published while its author was still alive to proofread it. Finally, when a printer was reading a manuscript notation, a cursive $1 / 2$, as then written, might appear as a 0 . So the actual number of Africans for whom Butts

\footnotetext{
the Dover Dogger with her rigging \&c., valued as per the enclosed at $£ 9815 \mathrm{~s}$. to the bearer, Thomas Butts of barking, mariner, in consideration of his long attendance on and services for his majesty at sea." The next day, it was granted to him "as a free gift in consideration of his long attendance on the King and his services at sea." Butts, a "fisherman and pilot," had previously petitioned for a pension "having performed in the late Dutch wars such signal services that his skill has saved his Majesty 100,0001." SP 29/229 f. 161, item 123. It is undated. The editor of the Calendar of State Papers Domestic (CSPD) estimates it originated in 1667. It seems to relate to Butts's actions in the Third Dutch War; the actual award of the ship followed on the decision in the case. Correspondence from February 1673/4 puts the Dover into battle off the coast of Spain and then heading to repair its mainmast at Alicante. For the 1674 report, see SP 29/341 f. 55, CSPD 1672-73, 533. In total, according to the report of July 27, 1676, the Dover Dogger and its pilot (Butts) had been at sea (and gone from London) for 28 months.
} 
had received no payment was between eleven persons (ten adults and one child) or up to twenty-one children. ${ }^{54}$

Crucial points about the case set a legal precedent that would be cited frequently in the following decades. Such King's Bench cases had large audiences, both for the initial hearing and in the printed "reports" of observers. Observers took notes that circulated in manuscript form and through ordinary conversation; the most influential reports were published. Common Pleas' Judge Creswell Levinz took the following notes, which circulated in manuscript before being published in 1701 .

TROVER for 100 [1 10 1/2] Negroes, and upon [pleading not responsible by the defendant, Penny] it was found by special Verdict, that the Negroes were infidels, and the Subjects of an Infidel Prince, and are usually bought and sold in America as Merchandise, by the Custom of Merchants, and that the Plaintiff bought these, and was in Possession of them until the Defendant took them. And Thompson [Penny's lawyer] argued, there could be no Property in the Person of a Man sufficient to maintain Trover, and cited Co. Lit. 116. That no Property could be in villains but by Compact, or Conquest. But the Court held, that Negroes being usually bought and sold among Merchants, as Merchandise, and also being Infidels, there might be a Property in them sufficient to maintain Trover, and gave judgment for the Plaintiff. ${ }^{55}$

The details of this judgment open a world of legal reasoning that we have lost and give deep insight into crucial features of later American slavery. The legal reference by the plaintiff's (Butts') lawyer, was to Coke's first volume of the Institutes, his section on the status of villeins (serfs), and to a discussion of whether feudal lords could own, buy, and sell them. That section articulated the obligations of villeins to their lords. Coke argued that a lord's power over a villein derived from the fact that the lord owned the land the villein worked. Because villeins held land "at the will of the lord," villeins had to repay their obligation. That obligation took the form of "Villein service; as to carry and recarry the Dung of his

54. See, for example, Colin Palmer, Human Cargoes: The British Slave Trade to Spanish America, 1700-1739 (Chicago: University of Illinois Press, 1981), 102, who gives an example of how new slaves were counted on a ship that arrived in Buenos Aries in 1725. Newly arrived Africans could be counted as $1 / 2,2 / 3,3 / 4$ or as 1 pieza.

55. 2. Lev. 201, in 83 Eng. Rep. 518. Creswell Levinz's Reports of Cases heard by the King's Bench was published first in 1702 in law French, with the approval of the then-sitting justices of the King's Bench, including Holt, as is printed verso to the title page, then republished in law French with English translation in 1722 (London: Nutt \& Gosling, 1722), 201. Levinz had died in 1701. This report seems very reliable except for the number 100; it is likely that the typesetter working from Levinz's notes was unsure what to make of the $10 \frac{1}{2}$ in the original notation (it is very strange if you don't know how the Assiento contracts for Spain worked!); $1 / 2$ as it was written then, in cursive ink, could look like an 0. https://slaverylawpower.org/butts-v-penny-1677/. 
Lord out of the City, of out of his Lord's Manor, unto the Land of his Lord, and to spread the same upon the Land." The image of taking the lord's dung out of the castle and spreading it on the fields provokes a laugh; however, it was serious business to spread fertilizer. Coke rooted that obligation in Roman law. "In ancient time," wrote Coke, citing Bracton, who wrote in the thirteenth century (and was influenced by Justinian), "the Condition of Villeins from freedom unto Bondage... grew by Constitution of Nations," not by the law of nature. Such rights grew from the rights of the victor after conquest as developed in the civil law. "He that was taken in Battel should remain Bond to his Taker for ever, and he to do with him, and all that should come of him, his Will and Pleasure, as with his Beast, or any other Chattel, to give, or to sell, or to kill." ${ }^{56}$ So Butts's lawyer was making an argument for absolute power that compared the rights of conquerors over those they captured to their rights over animals.

Penny, the defendant, was a plantation owner in Barbados. His lawyer (Thompson) invoked this passage from Coke to argue that Penny should not be liable for having taken the villeins, or "Subjects of an Infidel Prince" on the grounds that the lord did not have sufficient property "in the Person of a Man," to maintain a suit using this writ of trespass, since it applied only to things. The rights of a lord over his villein were limited by nature. One man could not own another, "but by Compact, or Conquest," according to the ancient law. As Levinz summarized Thompson's argument: "there could be no Property in the Person of a Man." It is ironic that the lawyer for Penny, a plantation owner, in trying to block recovery of a debt against Penny, was arguing against the principle of property in people; that he was doing so points toward the radical position taken by Butts and the RAC. ${ }^{57}$

Rainsford and the other justices on the King's Bench sided with this radical innovation, with Butts acting for the RAC on behalf of crown interests. In doing so they created a new precedent about the ownership of people, one that would reshape the common law. Butts could own ten and a half "Negroes" and recover them through long-standing procedures or writs that had long protected simple property in England, on the grounds that people were already "bought and sold in America as Merchandise." People who were "the Subjects of an Infidel Prince," could be held as

56. Edward Coke, The First Part of the Institutes of the Laws of England: or a Commentary upon Littleton, Not the Name of the Author only, but of the LAW itself (London: Elizabeth Nutt and R. Gosling, 1719) (hereafter Coke Upon Littleton), 1:116a, $116 \mathrm{~b}$.

57. See census of Barbados from 1680, TNA CO 1/44. 
property like hawks or dogs that one had trained to hunt, as in the cases that they cited as precedents. But they were exercising a logical sleight of hand. While people had been sold by merchants in the Americas, they had not previously been considered as "goods" under English law. The extent of the legal innovation is clear because neither lawyer, nor the case reports, could cite prior cases wherein humans had been considered goods. $^{58}$

The reference to "the custom of merchants" is especially obfuscating. The main English merchants in the new world to transact such business were employees of the King's Company, men like Butts himself, employees of the same king at whose pleasure, or not, Chief Justice Rainsford also held his appointment. In fact, as we have seen, the "custom of merchants" had not allowed recovery of debts via such a mechanism, had not agreed that people were things, which was exactly the problem. In 1676, just a year before, Charles Malloy's new standard guide to English merchant law, including merchant law in England's colonies, had actually said the opposite. It not only held that debts contracted in the colonies could not be collected in England, but also argued that wide-ranging methods that included imprisoning the bodies of debtors were largely fruitless. It noted that "Collonies or Plantations, . . . are governed by the Laws prescribed by the Souveraign. . . those Inhabitants, that shall resort thither, and there plant themselves for the good of the Place; and. . . have contracted debts far beyond their ability to satisfy, a failer of which, in strictness of Law, may (if the Creditor pleases,) oblidge their Bodies to Imprisonment; yet doth it not thence follow that the same ought to exacted; for though the Carcass of Men may gratify the revenge of the Creditor, yet it never can pay the debt." It said nothing about enslaved people as property. Instead it held that even a bond slave was a subject with limited rights. "By the Laws of England, every Subject Born within the Kings Dominions, is a Freeman of this Realm ...yea, though he be a Bond-Slave to a Subject." It clarified specifically that this rule of naturalization included the colonies "so those that are born at this day in Virginia, New England, Barbados, Jamaica, or any other of his Majesties Plantations and Dominions, are natural born Subjects, and not Aliens." Malloy thereby applied Calvin's case (1607) to make subjects of all those born on the English plantations, even those who were born a "bond-slave." 59 Butts's

58. These citations are included in Levinz's report.

59. Charles Molloy, De Jure Maritimo et Navali, or, A Treatise of Affairs Maritime and of Commerce (London: John Bellinger, 1676), especially 201-2, 389, 402; For a background on merchant law and civil law books in England in the seventeenth century, see Daniel R. Coquillette, "Legal Ideology and Incorporation II: Sir Thomas Ridley, Charles Molloy, and the Literary Battle for the Law Merchant, 1607-1676," Boston University Law 
lawyer's reference to the laws of merchants was therefore deeply misleading.

The second report on Butts v. Penny, by Joseph Keble, refers to the final verdict in the case that July. Keble emphasized the same key points, but illuminates more of the debate before the judge. "Special Verdict in trover of 10 Negroes and a half find them usually bought and sold in India, and if this were sufficient property, or Conversion, was the question." Again, the report identifies the question of whether "Negroes" could be property as the main issue in this decision. The bench had no precedent to cite that "Negroes" could be considered such property, other than this vague reference to merchants' customs in either "India" (America was also called the "Indies" or the "West Indies"). The report then discussed the same point that Thompson had raised, from Coke's Institutes, with the same page citation: "that here could be no property in the plaintiff more than in Villains; but per Curiam" by the vote of the majority of the judges, "they are by usage tanquam bona [just like a good] and go to Administrator untill they become Christians; and thereby they are Enfranchised." 60

In Butts v. Penny, Rainsford and the other three Kings Bench justices thus reversed existing precedents in the common law, including merchant law. They held that "Negroes" were not Christian, and hence not subjects, and that they could be traded as "a good" and litigated over as though they were a thing. The court awarded Butts the costs for his lost property, which the writ of trover allowed. ${ }^{61}$ The implication that "Negroes" who converted to Christianity might be freed was an important subsidiary issue.

Review 61 (1981): 315-74. Prior scholars, such as George Van Cleve and Jonathan Bush have taken this aside at face value, with no citations to merchant law. See, for example, Bush, "Free to Enslave." For more on Calvin's case and slavery, see Holly Brewer, "Subjects by Allegiance to the King," in State and Citizen: British America and the Early United States, ed. Peter Thompson and Peter S. Onuf (Charlottesville: University of Virginia Press, 2013), 25-51.

60. 3 Keble 785, from original edition in 1685. Joseph Keble, Reports in the Court of Kings Bench at Westminster from the $21^{\text {st }}$ to the $30^{\text {th }}$ years of the reign of our late Sovereign Lord Charles II, taken by Jos. Keble of Greys-Inn Esquire (London: W. Rawlins, 1685), 3:785. It concluded with a sentence that implied that Penny was one of several defendants: Judgment "lieth of moety or third part against any Stranger, albeit against the other coparceners." I believe that this means, not against the Royal African Company itself, but against anyone else with debts similar to Penny's.

61. 3 Keble 785, 84 Eng. Rep. 1011. The original version of this report was published in 1685 , (maybe even earlier as it appears there is a printed notation to page 35 on the side), so Joseph Keble's is the more reliable source. Keble was a lawyer and reporter (the main reporter on the courts) who attended the King's Bench regularly from 1661 through 1685, when his voluminous reports were published. Born in 1632 (the same year as Locke) his father was a King's Bench judge who supported Parliament but lost favor with Cromwell in 1654. See "Joseph Keble" in ODNB. Note that the scanned version of these reports on 
Most lawsuits required the use of a writ to be valid. To use trover, as in this case, required the definition that the court ended up specifying, that a person could be bona (Latin for a good), or a possession. The rule established here, that people are goods, opened a whole category of other writs for such litigation, including another type of trespass called detinue, which was even more useful for enslavers. While detinue and trover sought recompense for goods that someone else had taken, detinue allowed the recovery of the "good" itself (the enslaved person) as well as damages; trover allowed only for the recovery of the value of the good.

Applying these writs to humans substantially increased the powers of masters and slave traders and undercut rights claims by the enslaved in colonial and imperial courts. If planters refused to pay their debts to the $\mathrm{RAC}$, and if in such cases the RAC could not recover their "property" or receive damages for them, then they had no business. This case made ownership easy to enforce. It made the slave trade and slavery itself legally legitimate and enforceable across the English empire. It became much more difficult for enslaved people to claim any rights, or to litigate wrongs against them. This formal definition of people as property subject to contracts and regulation (in which they themselves had no part), made slavery legitimate via a legal fiction: people are not things.

$* * *$

Butts v Penny was only one example of how Charles II and his brother James II began to use judges as an extension of royal power. As Edward Foss noted in his biography of the Judges of England, the second half of Charles II's reign was a model of judicial corruption. "A direct proof of the attempt to render the judges subservient to the [Charles II's] court is to be seen" in the use of the words "durante bene placito," in judiciary appointments in the latter part of Charles II's reign and throughout James II's. Between 1677 and 1689 , no chief justice held his seat for more than 2 years. Foss's disdain is tangible: "No hesitation was exhibited in removing those judges who were deemed too honest and conscientious, and in raising others to the judgmentseat who were cringing candidates for popular applause or courtly favour, and who were likely to prove supple instruments for the ruling powers." ${ }^{\text {"62 }}$

EEBO has contemporary underlining and notes on the case, with a cross reference to Levinz's report, and the following passages underlined: "sold in India" and "untill they become Christians ... thereby they are Infranchised." That notation indicates that contemporary lawyers - at least one but probably others - were paying attention to these parts of this case (and paying attention to this case in general, as the other cases on these pages have no interlining).

62. Foss, Judges, 9:3-4. 
When judges were sworn with such conditional oaths, they had to be attentive to their king's wishes in order to keep their posts, not only in England, but in the colonies too. Charles II reached across to Barbados to directly order the suspension of judges who ruled contrary to his wishes, so in 1676 he ordered his Royal Governor Atkins to dismiss William Sharpe, Chief Justice of the main court at Bridgetown, for not acting sufficiently in the interests of the RAC. ${ }^{63}$ Foss's condemnation of the corruption of justice is exactly right.

To understand this point, imagine that any United States president could dismiss Supreme Court judges at will, say in the middle of the night before the imminent delivery of a judgment he did not like, and appoint new judges without Senate approval. The justices then were acutely conscious of their weak positions. Levinz, who reported the Butts case, had been a judge on the high Court of Common Pleas between 1681 and 1686, when James II dismissed him suddenly and without explanation. When the convention parliament asked him why, Levinz responded: "I thought my discharge was because I would not give judgment on the soldier who deserted his colours, and for being against the dispensing power." Levinz understood that he lost his post because he refused to support James II's standing army and refused to allow James II to ignore (to "dispense with") parliamentary laws. ${ }^{64}$

Andrew Marvell's criticism of corrupt justice was so strong that it would have meant his prosecution for sedition, had he not died first. In the spring of 1677, when Butts v. Penny was decided and then further deliberated, Marvell wrote: "Alas the Wisdom and Probity of the Law went off for the most part with good Sir Matthew Hales, and Justice is made mere property. This poisonous Arrow strikes to the very heart of Government." Marvell believed there was a conspiracy to make England into an absolutist dictatorship. "What standing Forces, what Parliamentary Bribes, what National Oaths, and all the other Machinations of wicked men have not yet been able to effect, may be more compendiously Acted by twelve Judges in Scarlet." ${ }^{65}$ For publishing such words (anonymously), Charles

63. The King to Governor Sir J. Atkins May 18, 1677, CO 389/4, 153 CSPC Item 255, 10: 90. "To remove William Sharpe, Chief Judge of the Bridge Court in Barbadoes, from his said office and supply his room by some other person qualified by his integrity and sufficiency for said employment according to his instructions in such cases."

64. "Creswell Levinz" in ODNB citing Cobbett, Parl. hist., 5.313. On the other hand, Levinz was viewed with suspicion by many Whigs because he had been involved in the prosecution of Lord Russell and in the attempt to suppress petitioning in 1679 .

65. Andrew Marvell, An Account of the Growth of Popery and Arbitrary Government in England more Particularly, from the long Prorogation [of Parliament] of November, 1675, ending the $15^{\text {th }}$ of February, 1676, till the last meeting of Parlimanet, the $16^{\text {th }}$ of July, 1677 
II's judges heavily fined the printer and threw him into the Tower of London (without habeus corpus), where he was pressured to reveal the author's identity. Marvell died shortly thereafter. ${ }^{66}$

In truth, regulation of slavery by judicial fiat was Charles II's only option. As we have seen, earlier efforts to pass parliamentary laws such as the 1674 attempt to define "in what manner, and upon what terms, slaves, either blacks or any other foreigners, may be used in England" had failed. Shortly after the bill was introduced, Charles II dissolved Parliament for other reasons, and the new Parliament he called the next year was less cooperative than the earlier Cavalier Parliament, whose members had held their seats since the Restoration. This was a time, of course, when the king could call and dismiss parliaments at his pleasure. Still, while he had influence over the choice of some members, particularly in what came to be called "rotten boroughs" he could not easily control Parliament.

So the king and his close advisors tried to control imperial policy without Parliament. Both the administration generally and the king himself were in close consultation with Rainsford over the Butts' case and its implications for slavery and imperial law in 1677. Rainsford rendered the first decision in Butts v. Penny in Hillary term 1677, which ran from January 11 to April 11 that year. When Rainsford gave the verdict, the Attorney General, Sir William Jones, spoke up. He "prayed" Chief Justice Rainsford to make the decision "nisi," that is temporary, until the next court term, so that "his opinion could be heard in this matter." In the next term, Pasche, or Easter, which ran from April 17 to June 5, Jones was not yet ready to weigh in, so Rainsford delayed the final verdict again. During those months, Rainsford as well as Jones were consulting closely with the crown. Jones brought the matter to the king and the Privy Council, who in turn consulted the solicitor general, the Lords Committee on Plantations, and the RAC. The main discussion occurred between July 17 and 24 . After all these centuries, we can only hear scraps of the conversation. In that first meeting on July 17, Jones (the Attorney General) and Sir Francis Winnington, the Solicitor-General, sought advice. They "desire to know their opinion whether negroes ought to he esteemed goods or commodities intended by the Acts of Trade and Navigation?" Did such a decision mean that the importation of "negroes" to the colonies could be taxed? Must all travel in English ships? How would it impact

("Amsterdam" [London], n.p. 1677), 66-67. Note that due to restrictions and fears surrounding publishing something so dangerous, it had a fake Amsterdam printer mark.

66. See Nigel Smith, Andrew Marvell: The Chameleon (New Haven: Yale University Press, 2010). 
the English slave trade with Spain (the Asiento), which the English crown was conducting through Jamaica? All agreed with the new designation, but wanted to somehow exempt the navigation acts from applying once it was rendered, as the redefintion of enslaved people as "goods" would mean that they also had to be taxed, a tax that would have to be paid by the RAC. It also potentially hindered England's ability to engage in the Asiento with Spain. On July 24, Charles II issued an order in council accordingly, confirming the initial Butts decision that "negroes were merchandize" but creating a workaround for the first of the legal dilemmas that the new category had created, and exempting the RAC from taxes. It was only then that Chief Justice Rainsford rendered the final decision in Butts v. Penny, and that it how it was recorded by Joseph Keble, as a final (no longer nisi) decision rendered in Trinity term, at the end of July 1667.

That attention reveals the case's significance, not only in the empire but also at home, both because its legal re-definition created other problems, and because the Privy Council and Committee on Plantations were dealing with so many other related issues for which they sought the chief justice's opinion. The deliberate re-definition of people as legal commodities would impact the application of the navigation acts. Indeed, within 6 more months, the Committee on Plantations tried to backtrack (at least on the exemption), deciding in January 1678, after months of debate that the new legal category should limit the ability of the RAC to engage in the Asiento. They appealed to the king to issue a new order in council, declaring that the Navigation Acts now clearly applied to black people imported as slaves, and that it was therefore illegal for Spanish ships to export them. ${ }^{67}$

During these same meetings, the Privy Council were also deep into deliberations about how to punish colonies and colonial governing bodies that did not conform to English law. On July 17, the same day the Privy Council began debate over Butts v. Penny, Chief Justice Rainsford met with them to offer his opinion on Massachusetts' laws. Yes, he agreed. Massaschusetts had made laws "repugnant" to those of England and should therefore lose its charter, particularly due to its failure to fully comply with the navigation acts. The decisions of the King's Bench, in other words, were happening in close cooperation with royal colonial policy making in the Privy Council and committee on plantations. Barbados' new 1677 law about people as property was not repugnant: Rainsford would make sure that the common law would

67. CSPC Col. Papers, Vol. XLI., No. 25, No. 44, and Col. Entry Bk., Vol. I., 76-78; January 22, 1678, CO 391/2, 211, the latter as cited by A.P. Thornton, West India Policy under the Restoration (New York: Oxford University Press, 1956), 80, n. 4, which has an excellent summary of English involvement with the Asiento between 1660 and 1689 . This would remain a point of contention. 
conform to an effective system of slavery. But Massachusetts, which was not generating nearly as much revenue, and had resisted the king's authority and sheltered regicides, would lose its charter and liberties for failure to conform to the Navigation acts. It was a busy month for Justice Rainsford. ${ }^{68}$

A related case involving the king, Justice Rainsford, a courtier named Sir John Reresford, and an unnamed black youth swirled around the court in these same months. Some years before, Reresford had been given a "fine Black" child "by a Gentleman who brought him over from Barbadoes." In early September 1676, the young man, then "about Sixteen Years" had died under suspicious circumstances. Rumors swirled widely, both in Reresford's community and around London, that the young man had died after Rereford had him castrated. As Reresford recorded: "At London it was credibly reported that I had caused him to be Gelt, and that the Operation had killed him." First the local coroner ordered that boy's body be exhumed to examine the corpse, but came to no determination. The king and many courtiers considered it a possibility that Reresford could be found guilty of murder, or at least manslaughter, and that his estate at least might be forfeit. Other courtiers were angling to obtain his estate, and Charles II intimated that might be a possibility. Reresford recorded that he had "heard that my Lord Yarmouth was one that had begged my Estate, upon the Occasion of the Death of my Black." Therefore, Chief Justice Rainsford, at the request of the Duke of Buckingham, gave another order to exhume and examine the body. But upon Reresford's appeal to the king that it was merely a "lye," Rainsford reversed his order. The investigation into the young man's death, therefore, was halted by the king's own intervention. The abortive attempts to investigate show the court's hesitations: Was killing a "Blackamore" a homicide? Reresford claimed that the "Blackamore" had died of a head wound and that the exhumation had shown his genitalia to be intact. But no one testified under oath after the king blocked it. The king's intervention here - in May 1677-in the midst of debate over whether "negroes" could be "goods," intimates that the king was at best stating merely that his courtier's life and reputation were worth more than the "Blackamore's". At worst, it indicates that the logic that people were things meant that any "Blackamore's" death would not legally be investigated as a homicide. ${ }^{69}$

Butts v. Penny had a profound impact on English law. In his important study of Black Lives in the English Archives, Imtiaz Habib sought to collect records for hundreds of years, and found that between 1500 and 1677,

68. CSPC Col. Papers, Vol. XLI., Nos. 22 and 23; and Col. Entry Bk., Vol. LX., 213-218.

69. John Reresby, Memoirs of the Honorable Sir John Reresby, from his Original Manuscript (London: Samuel Harding, 1734), 46-53. 
black men, women, and children appeared in many kinds of English and Scottish records, but especially in those of marriages and baptisms, on average once every 2 years. He reproduced these records in a substantial table that takes up half the volume, but he stopped his data set and his analysis in 1677. Why? The records, he notes, transformed, and he credits Butts v. Penny. He, too, acknowledges that it defined people as property, and caused a shift. While he doesn't explore that shift, he notes that there were many more legal, newspaper, and other records after 1677. In the earlier period, a majority of the black people he identified were not associated with any white person. That would change after 1677. Other scholars have likewise suggested that Butts v. Penny was transformative in England itself: James Walvin (1973), William Wiecek (1974), Leon Higginbotham (1978), and Amanda Bailey (2013). ${ }^{70}$

Rainsford's innovation was to rule that the subjects of so-called "infidel princes" could be claimed and recovered as legal property. Butts v. Penny's defining impact and legacy was that "negroes" could be "property," like a dog or hawk, the property in the cases it cited as precedents. Unlike villeins, then, slaves were not tied to the land as villeins regardant, a protection against sale that Coke had granted in his 1628 interpretation of feudal law. Butts v. Penny was a pivotal case that would be cited often throughout the next century. It was immediately followed by other trover cases for "negroes," such as Lowe v. Elton, also in 1677..$^{71}$

Whether cited or not, its logic infiltrated English law, such that lower court decisions, including those at Common Pleas, concurred that so-called "infidels" could be enslaved and traded as property. ${ }^{72}$ These cases were routine, and there were no doubt hundreds of them. Once the standard was set, they were neither reported nor published (although they can be glimpsed in references in other cases that were). ${ }^{73}$ So, for example, in the Court of Chancery a few years after Butts, Mr. Sargeant Maynard

70. Higginbotham, In the Matter of Color; Wiecek "Somerset: Lord Mansfield and the Legitimacy of Slavery"; Walvin, Black and White; and Bailey, Of Bondage, 25.

71. "Lowe v. Elton," King's Bench notes (manuscript compilation), Cambridge University Ms. Add. 9430, 2:373.

72. It is relatively rare for this case to be mentioned in the modern historiography, and when it is, the part that is usually emphasized is from the one report that mentions that conversions might enfranchise. At least one modern critic did note that the main point of this case was to establish property rights in slaves, although he did not realize that this case marked a turning point. Wiecek, "Somerset: Lord Mansfield and the Legitimacy of Slavery." Weicek also implied in that article that colonial case law about slavery rested on these precedents.

73. Bush, "Free to Enslave," argues that there were not many published, reported cases, and thus that these cases were infrequent. However only the most important cases were reported. Mundane cases did not rise to that level. 
"recovered a debt contracted against the executor of an owner of a plantation in Barbadoes" by means of a writ of "trover" and obtained judgment for "the fourth part of a negro" or one quarter of his/her value. ${ }^{74}$

Between 1677 and 1689, Butts v. Penny inaugurated a new era of rapid growth for the slave trade and an expanded system of credit in the colonies. Butts v. Penny had an impact on slave financing in the colonies within months. While in Virginia, planters grouped together to make one last prepurchase of 100 slaves on the royal exchange in 1678 (as they had done once before, in 1676, per James' declaration), was the last purchase made using the old model. By late 1677, the RAC began to issue credit to planters in Barbados to buy slaves on mortgages for terms of $3,6,9$, or 12 months. Consequently, debts owed to them by planters surged to $£ 120,000$ in 1680 and then to $£ 170,000$ in 1690 , but these were now circulating debts, with many paid off and a vastly expanded trade. The RAC also became more effective at recovering both its debts and its enslaved property. The consequence was that England's slave trade to its colonies finally took off. Between 1677 and 1689, the RAC's slave trade grew exponentially. ${ }^{75}$ The year 1678, when the new decision took effect, inaugurated a new era of consistent imports of slaves, as Figure 1 shows. Over the first 30 years of their existence, they recorded $26 \%$ of the sales of those they exported from Africa to be enslaved in their New World colonies (or sold to the Spanish); over the next 13, they recorded 74\%. From 1678 until 1689 (the Glorious Revolution) sales were relatively steady, comprising some 55,000 souls. $^{76}$

74. See Noel v. Robinson, 1 Vern 453, 23 Eng. Rep. 580, heard April 30, 1687 before the Lord Chancellor, which discussed Maynard's case as a precedent.

75. Price, "Credit in the Slave Trade," 300-301. It should be noted that Price does not explain why these changes were happening; he merely chronicles them. On the two Virginia voyages that depended on pre-payment contracts in 1676 and 1678, see Price, 302 , n. 14, citing 70/269. Virginians organized two more such sales later, but did so on credit. Also see Davies, Royal African Company, 294-97; and David W. Galenson, Traders, Planters, and Slaves Market Behavior in Early English America (Cambridge: Cambridge University Press, 1986), especially appendix A. For the Royal African Company's original account books, see TNA T 70/936-959. On the general question of credit and colonial property law (including property in slaves), see Claire Priest, "Creating an American Property Law," Harvard Law Review 120 (2006): 420.

76. Slavevoyages.org (May 16, 2021). The data from the Royal Adventurers to Africa and the Royal African Company imports are here combined as RAC. I used the "disembarked" as the relevant numbers, as those are the hard numbers based on the Royal African Company sales ledgers at different ports. The "embarked" data in the database are estimates. They provide a total of 74,635 records of slaves sold by the RAC between 1662 and 1690 . Of these, 55,280 , or $74 \%$, were shipped between 1678 and 1690 . The slave voyages database is full of estimates that rely upon algorithms. The data from the RAC account books are among the most reliable, but they are also incomplete; it is hard to run the numbers to exclude the estimations. 


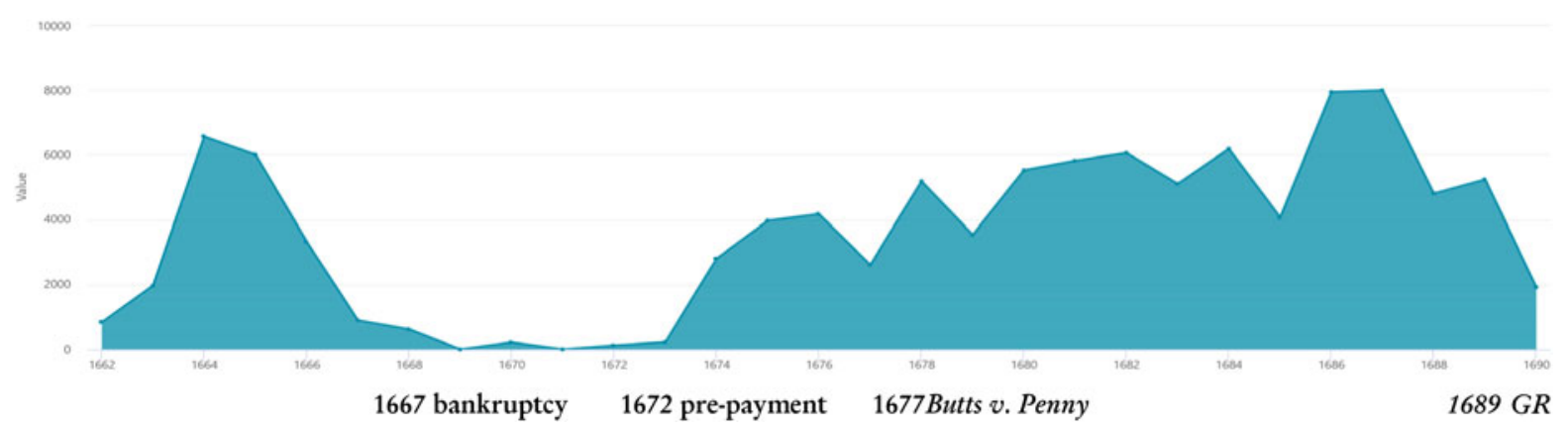

Figure 1. The RAC subcontracted their lease to a Guinea Company in 1669-71, which imported a small number of slaves. The blip between 1674 and 1676 was partly due to the Asiento, or England selling slaves to the Spanish through Jamaica. On the whole, the pre-contracting plan from 1672 proved slow to implement and unwieldy for the planters. Source: slavevoyages.org. 
When James II became king in 1685, he kept his post as governor of the RAC and remained involved in its business, actively protecting it and promoting it on many fronts. He did make one immediate change: while Charles II's Council on Foreign Plantations and Privy Council had decided in 1678 that, if slaves were merchandise, then they could not be exported by Spanish ships from Jamaica (the Asiento), James II issued an order in council to reverse it, thereby legalizing England's involvement in the Spanish Asiento. He did so immediately after his coronation, on April 29, 1685 . $^{77}$

Two years later, the King's Bench accepted its next major slavery case, Sir Thomas Grantham's Case. By this time, between Charles II and James II, justices on the bench had been repeatedly removed and replaced with ever more loyal justices. In the most infamous case, the 1686 case of Godden vs. Hales, the judges held that the king could "dispense" with parliamentary laws and was therefore above the laws. But James II was uncertain of their verdict beforehand. So he polled the high court judges personally and fired those who refused, after heavy-handed persuasion and direct threats. Justice Edward Neville later testified that "King James came to me for my Opinion in some Points, in a Paper he had in his hand; it was about the Dispensing Power of the Penal Laws." After several interviews with James II, the Lord Chancellor and others, he was finally dismissed and replaced. As the final date of the trial approached, the chief justice, Sir Edward Herbert, conducted an informal poll of the judges in a tavern to identify remaining doubters. Herbert's decision concluded that "he and all the Judges (except Street and Powell, Justices, who doubted) were of opinion, that the Kings of England were absolute Sovereigns; that the laws were the King's laws; that the King had a power to dispense with any of the laws of Government." It is notable that despite the king's efforts to fire all dissenters, two of the twelve remaining high court justices still abstained from the finding that "the Kings of England were absolute Sovereigns.",78

Only those who agreed that the "the Kings of England were absolute sovereigns" remained on the King's Bench the next year to rule on Sir Thomas Grantham's case, which hinged on an ambiguity in the Butts case and indeed in the larger justifications of slavery in the Atlantic world. What happened when "the subject of an infidel prince" who

77. Acts of the Privy Council, Colonial, 2: 81. Also see Thornton, West India Policy, 81, n. 4 (continued from the prior page). Thornton's long note on England's involvement in the Asiento doesn't connect it to Butts v. Penny or indeed to James's accession to the throne, but the pattern is shockingly clear. The Lords Committee had earlier recommended it (in November 30, 1684) CO 138/4, 278-9.

78. Sir Thomas Grantham's case, 3 Mod. 121; Godden v. Hales, 2 Show KB 475; "Debates in 1689: June 12th-20th," in Grey's Debates of the House of Commons, ed. Anchitell Grey (London, 1769), 9: 294-355. 
converted to Christianity could claim the right of a subject and was no longer outside the protection of the law (and, therefore, could no longer be claimed as property)? The verdict in Grantham's case was what one would expect when judges held their seats at the pleasure of a king who was also the governor of the Royal African Company and an active promoter of slavery and the slave trade: such persons could not form contracts, could be claimed as property, and had to be returned to their master.

Sir Thomas Grantham, like Thomas Butts, was a naval officer, who (also like Butts) had been an officer for more than a decade when the case emerged. Both had before reported to James, Duke of York when he was Lord Admiral, before he became king. Between 1672 and 1686, Grantham earned many laurels as a naval officer. As early as 1672, he was helping Virginians build forts to defend against Dutch incursions. He served routinely as the admiral in charge of the naval convoy that led the fleet of ships bringing Virginia tobacco to England, and English goods to Virginia. In 1676 and 1677, as the admiral protecting the convoy, he was the first British military authority on the scene of Bacon's rebellion. He was the officer who threatened that rebels with prosecution for treason, that the sword of the king's justice would be "sheath'd in your own Bowels" unless they surrendered immediately and brought an end to the rebellion. ${ }^{79}$ William Sherwood, one of His Majesty's commissioners who arrived shortly thereafter with a full regiment of a 1,000 men, reported from the James River in Virginia that Grantham had been "infinitely serviceable in reducing the country from ruin." His actions also upheld slavery and indentured servitude. ${ }^{80} \mathrm{He}$ then fought off Algerian pirates who threatened the Virginia tobacco trade, for which Charles II knighted him. Finally, as commander of the fleet in Bombay in November, 1684, he helped the British retain control of India by helping to suppress yet another rebellion, again via threats and negotiation, before briefly serving as Bombay's governor. ${ }^{81}$

Grantham returned to London in August 1685 with the man who would be the subject of his court case: "John Newmoone alias Shackshoone." James II welcomed Grantham in a formal audience at Whitehall, and would later shower him with recognition in the form of a golden chain

79. Grantham, An Historical Account of Some Memorable Actions, Particularly in Virginia; Also against the Admiral of Algier, and in the East Indies: Perform'd for the Service of his Prince and Country (London: J. Roberts, 1716), esp. 17-20. "Thomas Grantham" in ODNB. On Grantham's role in Virginia, also see Stephen Saunders Webb, 1676, the End of American Independence (New York: Knopf, 1984).

80. Sherwood to Secretary Sir Joseph Williamson, March 29, 1677, British National Archives CO 1/39, no. 54, in Calendar of State Papers, Colonial 10:43 (item 111).

81. Ray Strachey and Oliver Strachey, Keigwin's Rebellion (1683-4): An Episode in the History of Bombay (Clarendon Press, 1916), 142-57. 


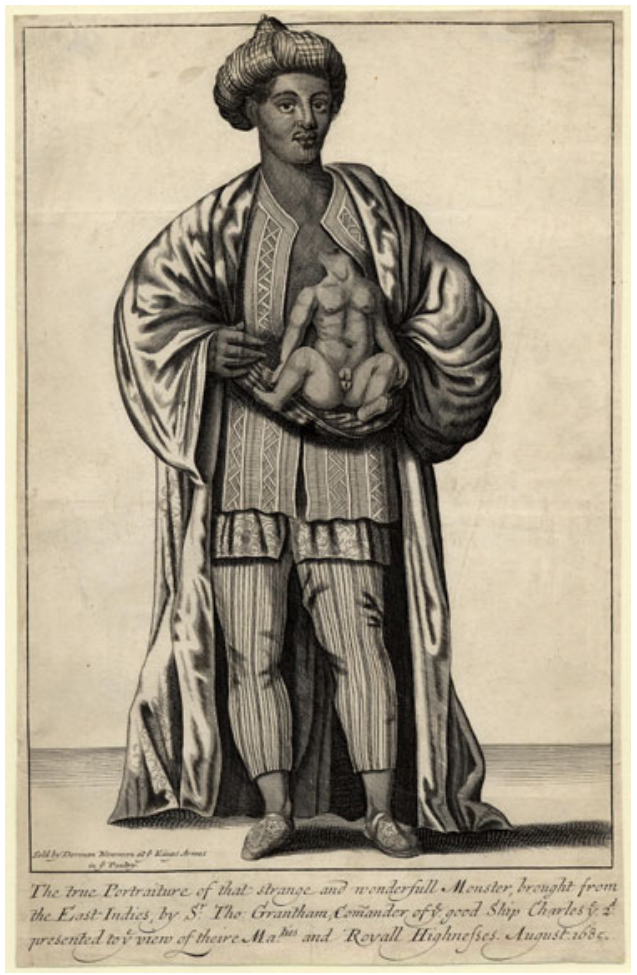

Figure 2. "That Strange and Wonderful Monster Brought from the East Indies" (London: Dorman Newman, 1685). Source: BM number 1852,1009.240. CThe Trustees of the British Museum. All rights reserved.

and medal. But Grantham did not come alone. Into the banqueting hall at Whitehall Palace, Grantham "brought from the East Indies" a "strange and wonderful monster" whom he presented formally to King James, Queen Mary, Princess Anne, and her husband Prince George of Denmark before the assembled courtiers.

Although from Bombay, the "monster" wore Turkish dress: a turban and a light and shimmery robe of silk. Under his robe was a shirt and an elaborately woven vest. His striped pantaloons reached to his ankles, from which emerged embroidered slippers. In almost every respect he looked normal, if exotic. In the engraving of him at his presentation that day, his skin is dark and his gaze steady and empathetic. But his shirt and vest are unbuttoned, and from his chest, held in place by a sling that encircles his shoulders, emerges the torso of a baby boy, legs splayed, genitals exposed. The baby's neck melds into his left breast; it has no head. The 
male baby is shocking to view, even today when such an anomaly can be explained: he was a conjoined twin; his brother had never grown because he had no thyroid. Then, he was a "monster," a strange and distracting and unexplainable curiosity (see Figure 2). ${ }^{82}$

Shankshoone and his brother Mahomet had signed indentures with Grantham in Bombay, in the spring of 1685, to come to England for 6 months. Shankshoone was "an Indian of unusual shape, having a Child growing out of his side," as Grantham wrote in a runaway ad. ${ }^{83}$ Newmoone's bizarre birth defect meant that he was described (repeatedly) as a "monster." He was particularly valuable to Grantham, because Grantham displayed him at fairs and markets, for money. The court case described his appearance and utility to Grantham almost scientifically. Grantham "bought a monster in the Indies, which was a man of that country, who had the perfect shape of a child growing out of his breast as an excrecency, all but the head. This man he brought hither, and exposed to the sight of the people for a profit."

In October 1686, however, Shankshoone and Mahomet ran away from Grantham's lodgings in Cheapside, and someone decided to help Shankshoone, in particular, despite the $£ 5$ reward that Grantham offered for his return. That person converted him, helped him get baptized and, finally, helped to protect him from his master on the grounds that he was now free. As the report of the case summarized: "The Indian turned Christian and was baptized, and was detained from his master." 84 Baptism, according to many, including the verdict in Butts, shifted the status of "negroes" from lifetime or hereditary servants to term servants. The logic seems to have been that subjects had a different legal status than aliens, and that the exclusion from the rights of subjects could apply only to aliens. But subjects had to be able to swear an oath of allegiance to the king - which meant they had to be Christian. Only then were they entitled to the rights of Englishmen. ${ }^{85}$

82. The engraving is listed as "The true portraiture of that strange and wonderful monster brought from the East Indies, by Sir Thomas Grantham," and dated August 1685. British Museum \# 1852,1009.240.

83. This description (and his name) comes from an advertisement that Grantham placed in the London Gazette of April 9, 1688 (issue 2337). His name was not given in the trial.

84. Sir Thomas Grantham's case 3 Mod. 121, 87 Eng. Rep. 77.

85. London Gazette, issue 2186, October 28, 1686. See Governor Hawley's 1636 decree in council that all "negroes and Indians" would from then on serve for life if they arrived without contracts. For more on this question, see Brewer, "Subjects by allegiance to the king," where I discuss Calvin's case and the question of allegiance in more depth. Katharine Gerbner, Christian Slavery: Conversion and Race in the Protestant Atlantic World (Philadelphia: University of Pennsylvania Press, 2018), especially ch. 1. See also, 
In response, Grantham sued to recover Shankshoone in February 1677, in a case that was quickly moved to King's Bench. ${ }^{86}$ Although the issue was similar to that in Butts-he argued that Shankshoone was unjustly detained by another - he used a different writ, de homine replegiando. It is a writ from feudal law that had been used by lords to recover their villeins. Grantham sought Shankshoone's return as well as monetary damages for his lost labor.

Two contemporary observers noted that the case also hinged on whether Shankshoone could form a contract. Shankshoone's petition stated that "Sir Thomas had contracted with him to come over from the Indies for six months and then to return but has kept him like a slave longer and got a great deal of money by showing him." Grantham ignored Shankshoone's indenture to claim what English law after 1677 would allow; namely, that he could hold Shankshoone as a slave. There is no evidence that the court cared about the contract. The court ruled merely that his conversion did not make him free and returned Shankshoone to Grantham. The verdict stated simply: "homine replegiando lies for a baptized infidel detained from his master." Fourteen months later, Newmoone tried to run away, and Grantham placed another ad in the London Gazette, again offering $£ 5$ reward for his return. ${ }^{87}$

Grantham's case consolidated related ideas about slavery and legal incompetence: Aliens and infidels could not make contracts; later conversion meant only that a different writ should be used to recover them. Like Butts, it also justified slavery of non-Christians-whether "Indians" from

among others, Rebecca Goetz, The Baptism of Early Virginia: How Christianity Chreated Race (Baltimore: Johns Hopkins University Press, 2012).

86. It is noted in the formal report as heard in "B.R." which means "Banco Regis" or King's Bench. However it was apparently moved up from the Court of Common Pleas only because Grantham had initially made an error in not specifying that Shankshoone was his property; note that the man Grantham brought suit against was "bailed by the court of common pleas" and also that a popular report of this case (see Note 87, from Greenwich Hospital Newsletter) stated that it was being heard by the Common Pleas.

87. This account was published in the Greenwich Hospital Newsletter, 5 February 1687, which reported news related to the Admiralty; no doubt rumors about this case were reported because of Grantham's rank in the Admiralty. The Greenwich Hospital Newsletter is reprinted in the CSPD, James II (London: Her Majesty's Stationary Office, 1964), 2:359. "On Thursday at the Common Pleas was a trial between the monster (a man that hath a child growing out of his side) and Sir Thomas Grantham upon a writ de homine replegiando. Sir Thomas had contracted with him to come over from the Indies for six months and then to return but has kept him like a slave longer and got a great deal of money by showing him; so he prays to be relieved according to law. The judges (it being a novel case, though the man has been christened since he came here) will consult all their brethren about it and have since ordered him to be bailed." The outcome did not accord with the optimism of this entry. Grantham again advertised for Shankshoone's return in the London Gazette, April 1688. 
the East or West Indies or Africans - in England itself. Given that Shankshoone had initially negotiated a contract, the latter was an especially powerful statement. As Richard Newdigate, a JP, wrote in his manuscript newsletter: "Sr Thomas haveing Contracted with him to Come hither from the Indies for 6 Months \& then to Returne But hath kept him like A slave longer to shew him." 88 Grantham's Case thereby closed the conversion loophole left by Butts v. Penny, making the status of non-Christian aliens who arrived in England potentially permanent. At the same time, as explored later in this article, this writ was trickier. It recognized the humanity of the enslaved (since it used the law of villenage) and it was a solution that often ended up imprisoning masters, so thus was not politically palatable.

Grantham was one of many who benefited not only from royal patronage, but also from their advocacy of slavery and absolutism. ${ }^{89}$ The judges who ruled in his favor were also benefiting from Stuart patronage. Indeed, Andrew Marvell's charge that "justice is made mere property" has a strangely compelling resonance. Charles II and James II manipulated the system of justice openly, by buying or swaying the favor of men then disparagingly called "creatures." While such dependence, and ideas about hierarchy and divine right were older than Charles and James II's reigns, legal procedures that encouraged absolutism became more embedded in the institutional structures of governance between 1660 and 1688 .

The Glorious Revolution of 1688 initiated substantial changes, including who wore the red robes of the high court of King's Bench. The Convention Parliament that assembled in January of 1689 took it upon itself to fine and imprison all the judges of the common law courts. The twelve high judges of the King's Bench, Common Pleas, Exchequer, and also Chancery were each fined $£ 500$, exempted from the general pardon that William and Mary had promised, and prevented from holding any future office. Normally, common law judges were reappointed at the start of a new king's term, as they were when James II succeeded his brother. ${ }^{90}$ The Convention Parliament took this step to replace all the high court judges because they saw the high court as the source of the practical absolutism of James II.

88. For this quote, see Richard Newdigate's newsletter from February 1687, manuscript transcription pp. 1481-82, Folger Library.

89. Grantham, Memorable Actions, 54.

90. Alfred F. Havighurst, "The Judiciary and Politics in the Reign of Charles II," Law Quarterly Review 66 (1950): 229-52. 
The Convention Parliament studied the judges' decision in the case Godden [or Godwyn] v. Hales in 1686 as prima facie evidence of how James II's aspirations to absolutism had corrupted the bench. Beginning on January 25, they demanded the full records of the case, and proceeded to pore over them and debate their course. ${ }^{91}$ They decided that all the judges who had participated in the Godden v. Hales decision that said, essentially, that the king could ignore parliamentary laws, had to be punished, even the one (of twelve) who had disagreed with the verdict. $^{92}$

The new high judges of the common law and chancery courts were jointly chosen by William and Mary's new Privy Council and the Convention Parliament. ${ }^{93}$ John Holt's name sat at the top of their lists, apparently because of his earlier resistance to James II's attempts to increase his own power vis a vis Parliament via the courts. In particular, Holt had denied that James II could dispense with parliamentary laws (the 1686 case of Godden v. Hales) and had also resisted Charles II's revocation of the charter of the City of London in 1683. In April 1689, during the Convention Parliament, it was he who made the most powerful argument for dissolving James II's claim to the throne. He argued that William and Mary should not merely be regents, ruling during a period of James II's insanity, as it were; instead, the Convention Parliament should declare that James II had "abdicated" the throne, not only by his flight after his military defeat, but also because "government is under a trust." James II had violated his oath, and should, as it were, be impeached. "A deliberate violation of that trust is an express renunciation of it, although not by formal deed. How can a man in reason or sense more strongly express a renunciation of that trust than by subverting it, his actions declaring more strongly than any words spoken or written could do that he utterly renounces it?" 94 James II's open aspirations to absolutism

91. See Grey, Commons Debates, especially May-June, 1689 (esp. May 15, and June 12-18).

92. See the Convention Parliament proceedings from January 25 to 27, 1689, "Ordered that the Officers of the Court of King's Bench do immediately attend this House, with the Records of the Judgment in the Cased of Godwyn and Hales, and of the Information prosecuted against the Seven Bishops" (344) Also see Grey, Commons Debates, proceedings for May and June of 1689. William and Mary appointed Sir John Holt as Chief Justice on May 4, 1689 (along with three others on the same day, Sir William Dolben, Sir William Gregory, and Gyles Eyres, esq.), The Life of the Right Honourable Sir John Holt, Knight, . . . (London, J. Worrall, 1764), 5.

93. Lord Campbell, The Lives of the Chief Justices of England, seventh ed. (New York: Cockcroft \& Co., 1878), 3:17.

94. Lives of the Justices, 3:12-13 . Note that on "Sir John Holt" in the DNB, Paul Halliday claims that Holt "defies easy labeling as a Whig or a Tory" and that sometimes 
had violated the trust placed in him. Any king of England should have limited powers. Therefore, he contended, William and Mary should be proclaimed king and queen.

Holt thus offered the then-radical position, that when a king became a tyrant, the people had a right to rise up against him and choose another. Such a king, who was "an advocate for slavery," could justifiably be overthrown, as Locke stated in the preface to Two Treatises of Government, published in 1689 to justify that revolution. ${ }^{95}$ These were the arguments of many Whigs, and of William and Mary's firmest adherents. They held little power at the beginning of William and Mary's reign. But after Mary's death in 1694, and after an attempt by Tories to assassinate William in February 1696, the balance shifted decisively to them, and to a group whom contemporaries called the "Whig Junto" in particular. After 1696, the full impact of the revolutionary ideology began to be felt, particularly as it related to slavery, not only in England but also in its empire.

While the Glorious Revolution (and Holt himself) did challenge absolutism from the beginning, William and Mary did not challenge, at least at first, the enslavement of "infidels" in the same way. Slavery was a subsidiary issue, one that did not compel the same alliances as the larger issue of absolutism. William III was presented with the immediate problem of whether to continue England's involvement in the Spanish Asiento. During the 1680s, Charles II and his brother James's RAC had been building an extensive trade with the Spanish, supplying them with slaves via resale in Jamaica. The trades were facilitated by a Spanish factor, through most of the 1680s a man named St. Jago del Castillo. Although such a trade technically violated the Navigation Acts after 1677, they had been negligently enforced between 1677 and 1685, and after 1685, as we have seen, James II had ordered that they allow the trade (another example, incidentally, of James' disregard of parliamentary laws). ${ }^{96}$

In 1689, however, James II's role in the Asiento, or the RAC providing slaves to Spain through Jamaica, provoked a crisis. New authorities in the

\footnotetext{
Holt sided with the James II's side in King's Bench cases from the 1680s, especially the East India Company case. However Holt took the opposite side in many cases, indeed in many politically sensitive ones, providing counsel to Lord Russell, for example, who was convicted of treason in the Rye House Plot. I would argue that Holt threw in his lot wholly with the Whigs after his dramatic denial of James II's dispensing power in 1686, when he was recorder of London, after which James II requested his resignation (it was another post held durante bienplacito). See Lives of the Justices, 3:12.

95. Locke, preface, Two Treatises.

96. On this trade with Spain via Jamaica in the restoration period, see n. 66 above and Gregory E. O'Malley, Final Passages: The Intercolonial Slave Trade of British America, 1619-1807 (Chapel Hill: UNC Press Books, 2014).
} 
islands were clearly bent on enforcing the Navigation Acts' rules against goods traded to other countries, which threatened both the RAC's profitable business and the Spanish supply of new African slaves. In the words of the Spanish ambassador, "The [Spanish] person in charge of the negotiations respecting the introduction of negroes into America is ready to start for Jamaica, but he cannot start nor fulfil his duty without previous solution of the existing differences as to the purchase of negroes in the British dominions, and their free transport in his own vessels to the dominions of Spain."

Note the diplomacy: The RAC is not mentioned, and the quote reads as though the ambassador is trying to buy "negroes" already there (not newly imported African people) from British colonies and take them elsewhere. The Spanish Ambassador continued, "I beg therefore to remind you of the matters already brought before you, and since they cannot be settled as soon as could be wished, I would ask the King at least to permit the practice which has already existed more than twenty years to continue for the time until these difficulties are decided, and that he will give orders to the Governor of Jamaica and of the other Colonies not to trouble St. Jago del Castillo nor his dependents in the execution of their duty." William, sitting with his Privy Council, referred the matter to Sir John Holt and the other judges of King's Bench for their advice. ${ }^{97}$

Holt and the other new justices on the King's Bench — at this pointupheld the principle established by Butts $v$ Penny: that "negroes are merchandise." However they did so to block the agenda. They urged William to reverse James II's order in council from April 1685 that had suspended the Navigation Acts to allow the Asiento. While the judges allowed that "It is not against law for ships in distress to enter Colonial harbors to replenish and refit," that right did not extend to exporting "negroes." A8 As Roger Morrice, a Whig politician, wrote in his diary for December 1689.

Judices [The Judges] About the Close of the last month [November 17] the Crown sent for all the Judges and craved their Opinions. Question: Whether the King by Law might authorize the Spaniard to buy and sell, and make Merchandize of Negroe's in his Dominions beyond Seas, as in Jamaica \&c Some of the Judges seemed to thinke it was unchristian and impious, but they were unanimous in their opinion, that though it had been done by former Kings, yet our Law did not Countenance it nor warrant it \&c. The Attorney

97. "Memorial of St. Jago del Castillo, CommissionerGeneral for the introduction of negroes into the Spanish Indies," August 20, 1689, TNA CO 138/6, 203-5; Memorial of the Spanish Ambassador, n.d. [Nov. 1689?], TNA CO 137/2, 60. One person at least objected in writing: Arthur Moore, whose "objections" were annexed to Castillo's memorial.

98. "Report of the Judges on the memorial of St. Jago del Castillo," November 11, 1689. TNA CO 137/2, 58, CO 138/6, 285. Summarized in CSPC Item 542, 13:173. 
Generall and Solliciter had before delivered their opinions to the same purpose.

However, as Morrice reported, William and Mary then ignored the judges' advice. "Notwithstanding the Court [Crown] has given out such Commission to the Spaniard and Printed it in this Gazette." Morrice noted that William and Mary should never have consulted the judges if they planned merely to ignore them: "Some thinke it had been rather better if it had been done without Consulting the case" to the justices (Figure 3). ${ }^{99}$

This Asiento case was the only one related to slavery that the high court of King's Bench heard or advised on during the early years of William's reign, and while it did not repudiate Butts, it was only an informal opinion. At least one other case, heard in the Court of Common Pleas, merely upheld Butts: there were doubtless others. In Gelly v. Cleves, Sir George Treby, a Whig justice, ruled simply that "trover will lie for a Negro boy; for they are heathens, and therefore a man may have property in them, and that the court without averment made will take notice that they are heathens." 100 Since the lower Court of Common Pleas was supposed to follow the King's Bench decisions, that was to be expected.

By 1696, however, after an attempt on his life, the king himself decided to take a stand against James II's imperial policies towards slavery, personally appearing in the court of King's Bench to accept just such a case. $^{101}$ On October 26, 1696, the King's Bench meeting at the Guildhall in London accepted a civil suit over a slave from Barbados, one which, like Butts v. Penny, relied on a writ of trespass. Willoughby Chamberlayne, the plaintiff, was a prominent Barbadian who had recently been speaker of their assembly and was in London seeking to become governor. He wanted to recover someone he claimed as a slave from a London resident named Robert Harvey. Chamberlayne's grandfather's wife had brought the enslaved man from Barbados as her dower (in whom she had only a temporary, or life estate), about 10 years before. That man

99. TNA CO 137/2; Roger Morrice's Entring Book, ed. Mark Goldie (New York: Boydell $\&$ Brewer, 2009), 5:308 (entry for December 1689). Holt also decided the Nightengale case, which involved a ship going to Africa with trade goods, but was not directly about slavery. The Nightengale case of 1689 protected the provisions and ammunition and the ship itself of a ship trading to the coast of Africa and holds that the admiralty court that Charles II had set up is illegal. It restored the goods and challenged monopoly power of the RAC but said nothing about slavery. I discuss that case more below at note 112 .

100. Ld. Raymond 1: 147.

101. The records state that the king himself was there. It is possible that this was a formality of wording, but if so, it is not repeated in other reports. Either way, it is clear that the new case had his approval. 


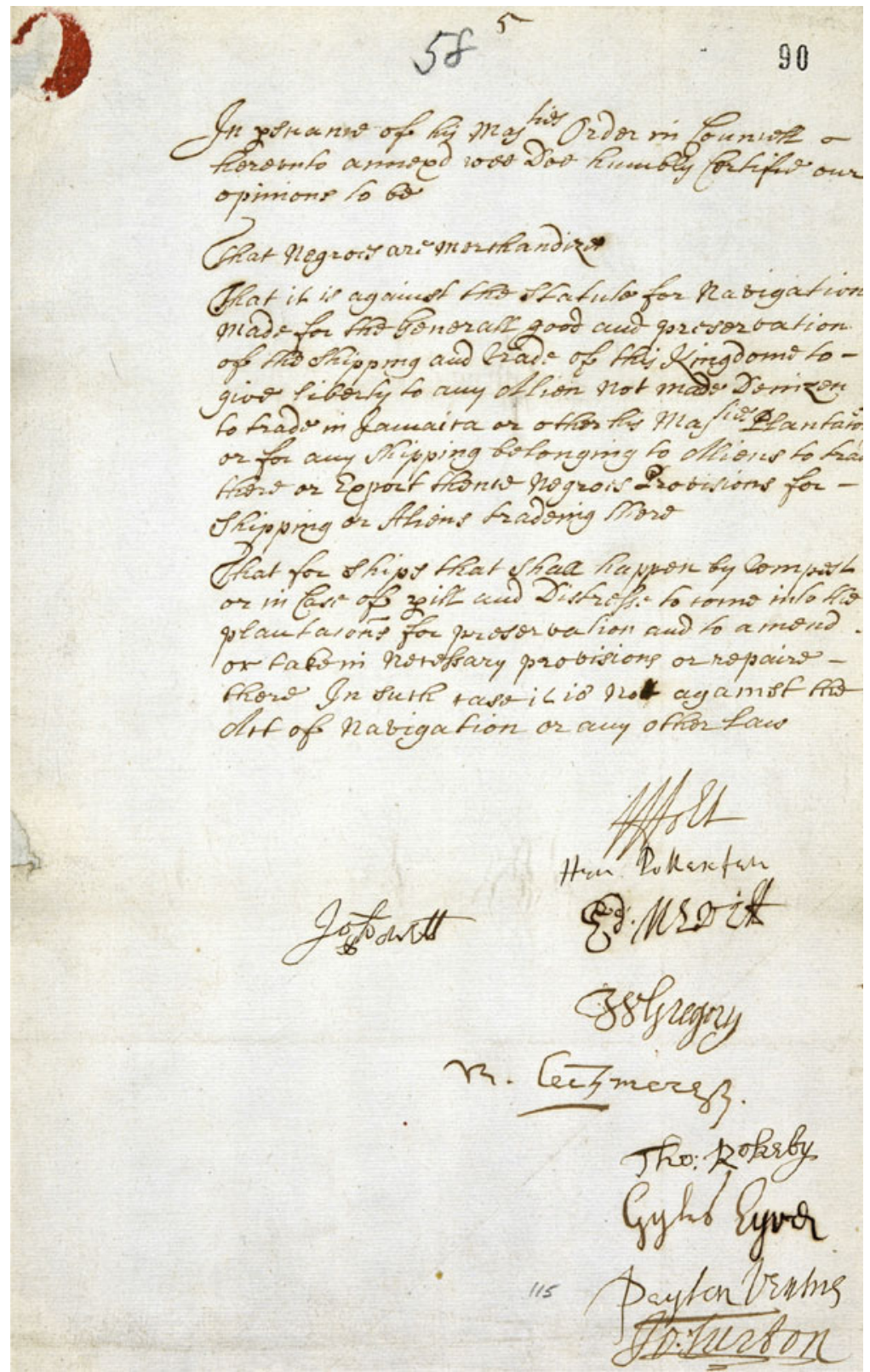

Figure 3. "In Persuance of his Majesties Order in Councill -Hereunto annexed wee Doe humbly Certifie our opinione to be That Negroes are merchandize." Note the original signatures of the ten judges at the bottom of the page, beginning with Holt's. Source: TNA CO 137/2. 
was now working for Harvey. ${ }^{102}$ Willoughby claimed that Harvey had taken away his "slave worth 100 pounds" and then "kept possession of him" and sought return of the man plus damages. The writ, called detinue, was of the same family of torts as trover; while trover sought merely the recovery of the good's value; detinue allowed for the recovery of the good itself plus damages. Both were categories of legal actions of trespass: if a writ of trover was legal to recover the value of a slave as though that person were property, then detinue was legal too.

Harvey responded that he had hired the man for wages of $£ 6$ a year, so therefore he was an employee (not a slave). The name of the man they argued over was never stated. Willoughby's lawyer called him a "negro slave." Harvey's lawyer called him a "man." That he was never named reveals his individual irrelevance. A principle was at stake: could one man own another? Harvey, who had employed the man whom Willoughby claimed to own, argued that he should neither have to return the man, nor should he have to pay damages. He then begged for a jury to discover and assess the facts (something juries did then, but would not do now). A week later, on November 3, Chief Justice Holt impaneled that jury, granting them 3 weeks to find and review the evidence. ${ }^{103}$

Even the calling of a jury before the high court was an unusual act; so, too, was the presence of a king and the hearing of a case in the high court that could have been heard in a lower court such as Common Pleas, just as Gelly vs. Cleve had been 2 years before. Clearly, the court intended to either reassess or reverse earlier rulings. The importance of Chamberlayne v. Harvey can be gauged by the fact that so many lawyers and judges reported and shared its findings. Reports on the case were printed in

102. Chamberlayne is a fascinating character; during James II's reign he converted to Catholicism, for which he was briefly imprisoned after the Glorious Revolution by the then-governor Stede in 1690, before reconverting to the Anglican Church and being chosen speaker of the Assembly in 1692. See Lieutenant Governor Stede to [the Earl of Sunderland] March 17, 1687 TNA CO 1/62, Nos. 11, 11b, CO 29/3, pp. 412-414; Stede to Lords of Trade and Plantations Oct 5, 1688, TNA CO 1/65, Nos. 65, 65I.-XXXII., and |CO 29/4, pp. 33-63; Minutes of Council of Barbados Feb 24, TNA CO 31/4, pp. 112-120; A collection of papers relating to Sir Thomas Montgomerie and Willoughby Chamberlayne, enclosed with the foregoing despatch May 30, 1689 TNA CO 28/37, Nos. 7, I-LXV; Stede to Lords of Trade and Plantations, April 23, 1690, TNA CO 28/1, Nos. 27, 27 I., |CO 29/4, pp. 205-213; Journal of Assembly of Barbados, April 15, 1691, TNA CO 31/3, pp. 265, 266; John Blanton provides a Marxist, synthetic survey of these cases and explores more about Chamberlain's later life in "This Species of Property: Slavery and the Properties of Subjecthood in Anglo-American Law and Politics" (PhD dissertation, CUNY, 2016).

103. On the practice of juries serving as witnesses and collecting evidence, see John Marshall Mitnick, "From Neighbor-Witness to Judge of Proofs: The Transformation of the English Civil Juror," American Journal of Legal History 32 (1988): 201-35. 
detailed form in at least three places and summarized in two more for a total of five printed reports. The first reports are also of an extraordinary length, repeating in detail the arguments as well as the evidence. Other notes were also circulated, commented upon, summarized, and digested in manuscripts. Compared to most cases, which took up no more than a paragraph, and were reported at all by perhaps only one observer, this was extraordinary attention. ${ }^{104}$

The jury summarized the evidence in a way that captured how slavery was legalized throughout the empire, by describing it in feudal language but combining it with the new argument that made villeins into "so absolute a property." The jury "say upon their oath, that one Edward Chamberline, long before the within-written time when \&c. was seised of a certain plantation in the island of Barbados in the West Indies, in parts beyond the seas in his demesne as of fee, and of certain negro slaves, being slaves belonging and appertaining to the same plantation; and the aforesaid negro slave, long before the within-written time when \& c. was born of negro parents, slaves belonging and appertaining to the same plantation; and that long before" the 1668 act that made slaves into real estate, a law passed to ensure that "the heirs and widow who claim dower may not have bare lands without negroes to manure [fertilize] the same." By the law "all negro slaves . . . shall be held, taken and adjudged, to be estates real, and not chattels" except that slaves do not have to pass by deed, as do lands. This passage shows that by making slaves "real estate," Chamberlayne and his lawyer, and indeed the Barbadian legislature, were trying to claim that slaves were villeins, and that property could thus be established in them on that basis. Note several crucial clauses "long before the within written time," as in almost forever, and the claim that their role was to "manure" or fertilize the lands, exactly the main tasks that villeins were supposed to perform according to Coke, as discussed in Butts v. Penny.

One supposed slave descended to Mary, the widow of Edward Chamberlayne, as her dower share, with the reversion to William Chamberlayne, whose heir in turn was Willoughby Chamberlayne (which means that after she died, he would inherit, as she had a temporary, then called a life, estate). Meanwhile, Mary had married John Witham, and they both moved to England in 1684. Between 1684 and 1695, the "said

104. The five published reports are two reports in Modern Reports, the second of which describes the arguments in the case, 5 Mod. 182, 186 (87 Eng. Rep. 596, 602); Lord Raymond's Reports (again in two parts), 1 Ld. Ray. 146. (91 Eng. Rep. 994), 3 Ld. Ray. 129. (92 Eng. Rep. 603); and Carthew's Reports Carth. 396. (90 Eng. Rep. 830). The originals are reproduced and transcribed at https://slaverylawpower.org/chamberlain-v-harvey1696/. Most of the quotes below are from the collected notes in Modern Reports (London: E. and R. Nutt and R. Gosling, 1738), 182-191. 
negro slave" was baptized. Witham also "put the said negro slave out of his service" after which he (the former slave) took various jobs. In about September of 1695 , Willoughby tried to reclaim the man he claimed as his slave. However Harvey refused to relinquish him, instead re-hiring him for wages of $£ 6$ a year, thereby creating a legal contract.

The fact-finding jury offered no verdict. They confessed themselves "wholly ignorant" of whether Harvey should be fined, and sought guidance from the court. The justices of the King's Bench, led by Holt, then posed the following queries to Chamberlayne, Harvey, and their lawyers. (1) Upon the jury's finding, was "any legal property vested in the plaintiff"? (2) If Chamberlayne did have such property, did not bringing the man to England void it (and constitute a "manumission" as the status of villeins was only in relation to the land they occupied)? (3) Does an action of trespass lie for a "Man of the price of one hundred pounds?" The fact that they used the word Man, italicized in one published report, indicates the direction of their thought and how their words were interpreted by the large audience of lawyers and judges assembled to hear the case.

In response to these queries, lawyers for both sides mounted vigorous rationalizations of their positions. Godfrey Woodward, lawyer for Chamberlayne, sought feudal and Roman precedents for lords owning villeins or slaves. He claimed that "The power which naturally arises to the lord over such bondmen or slaves, is by reason of his supplying them with food and raiment during their lives, as a recompense for their labour: such is the usage of the island of Barbados." He continued that "this negro was born of negro parents there. Now the children of such parents are slaves as well as they. So it was amongst the Romans; where both parents were aliens, the children were so too." His arguments here reveal how early justifications of slavery invoked Roman laws about the status of an alien in contrast to a subject or citizen, in order to deny rights to those designated as aliens. The passage intimates that the baptism of "aliens" would be so troublesome, because such baptism could make aliens into subjects with rights.

Chamberlayne's lawyer then argued that such slaves were nothing more than villeins, "regardant to a manor," and thus were completely in accord with ancient English law, by "which the lord had so absolute a property." He finished this section floridly, with a claim that Butts v. Penny had shown "that trover will lie for a negro" under English law, regardless of the location. If trover lies for slaves, then people can be property, and all of England's complex property law can be deployed to protect that ownership.

For Chamberlayne's side, the only potential flaw in his case was this man's conversion to Christianity. So that "the chief question [of the 
whole case] then is, whether baptism without the privity of the lord will amount to a manumission?" He answered that a villein could not be manumitted from a lord's power without the lord's consent "but where the Lord is an actor." Indeed, "what the villein does without the consent of the lord, cannot acquire a manumission." He closed his case with what he doubtless expected to be the decisive argument- one of practicality due to the changed political climate and ideology of the new monarch: "If baptism be accounted a manumission, it would very much endanger the trade of the plantations, which cannot be carried on without the help and labour of these slaves."

Harvey's lawyer then rose before the justices. He utterly rejected Chamberlayne's careful logic. "It is against the law of nature for one man to be a slave to another." While he admitted that there might be some cases in which a man would bind himself to another, or be taken as a prisoner in war, and because he owed his life to the man who saved him, offer service in return, "no such thing is found in this verdict." $\mathrm{He}$ was explicitly setting aside, therefore, the narrow justifications for slavery in Locke's Second Treatise. But even that, he rejected. The law of nature, he finished, does not justify slavery, but only the constitutions of nations (man's law). These constitutions of other nations do not accord with England's law. "Our laws are called libertates Angliae, because they make men free; and therefore even in the time of villenage [feudalism] here, the lord had not such an absolute property over his slave." Stone then listed the rights that even villeins bore, such as the right to challenge their masters in court.

Moreover, he refused to grant that what Chamberlayne was claiming as legal in Barbados or in England was feudalism. To make slavery legal on such a basis, he said, was ridiculous. "This cannot be a villein regardant to the plantation, for then the plaintiff and his ancestors must be seised of this negro and his ancestors time out of the memory of man, which could not be, because Barbados was acquired to the English within time of memory." He thereby destroyed the mythology that Chamberlayne's lawyer had created (with the help of the jury) in their description of "long before the within-written time when \& c. was born of negro parents" whose families had always been bound to that plantation. Even if Chamberlayne had a limited right to own another in Barbados as a lord over a villein, migration to England voided that right because villeins belong only with parcels of land and, once they are removed, the obligation vanishes. He utterly rejected the idea that people could be property anywhere in England or its empire. Magna Carta prevented one man having "absolute or general property" in another.

Harvey's lawyer concluded by closing one final loophole. Because Harvey's employee, the "man," had converted to Christianity, he deserved 
full access to rights. "Being baptised according to the rite of the Church, he is thereby made a Christian, and Christianity is inconsistent with slavery." He justified this with complex arguments that also went back to the medieval period and emphasized the limits of lords' powers over villeins who wanted to become monks or travel to holy places. In conclusion, he gestured at an argument that, although profoundly different, was probably as powerful as the one that Woodward had offered in his closing remarks. Stone discussed norms among the Turks. The Turks, as recently as 1683, had stormed the Christian West at the gates of Vienna, enslaving Christians along the way. But even they "do not make slaves of those of their own religion." If a slave converted to the Muslim faith, they were entitled to freedom. "If this be a custom allowed amongst infidels, then baptism in a Christian nation, as this is, should be immediate enfranchisement to them, and they should thereby acquire the privileges and immunities enjoyed by those of the same religion, and be intitled to the laws of England." A baptized person of African descent should be able to claim the rights of any other English subject. This argument was common in the 1690s, and the threads went back as we see in the Merchant's law book of 1676, to Calvin's case in $1607 .{ }^{105}$

The judges rejected Chamberlayne's claims to own the unnamed Black "Man." Chamberlayne was left with the costs of the case. He had no slave, no money for damages, and no validation of the claim that slaves could be property. The judges' verdict was that "no action of trespass would lie for the taking away a man generally" and thus that writs to protect simple property (trover and detinue) could not apply to human beings. Although they admitted that in some cases a master could bring a special action for the loss of his apprentice's labor when there was a contract by way of a writ "per quod servitium amisit," this was a narrow writ that did not apply to this case, where no apprentice had signed a contract. The earliest and longest report on this case showed the justices agreed with the defendant. Chamberlain "could not have an absolute or general property, because by the magna carta, and the Laws of England, no man can have such a property over another." 106

It was a verdict that echoed far beyond the walls of London's Guildhall and made plantation owners in Barbados shiver, because the King's Bench decisions under Holt, of which this was merely the first, blew a gaping hole through the legal structure of slavery and the slave trade across the empire. The legal reversals in London had a direct and immediate effect on the ground, in terms of the ability to finance slave purchases. In 1697, the

105. For more on this question, see Brewer, "Subjects by Allegiance to the King," 106. Modern Reports, 189. 
year after Chamberlayne, the RAC returned to the policies of pre-1677 to demand immediate or pre-payment for African slaves, refusing to issue credit unless the company's factor in the colony was willing to issue his personal credit. As a consequence it returned to a barter or market system of immediate payment almost completely. Not until 1710, and really not until 1713, did the RAC (and the new separate traders allowed by the 1698 act) once again begin to issue long-term contracts. While the slave trade expanded briefly as a result of the 1698 act and so many new investors, it contracted again until after 1710. The RAC, meanwhile, went from having a monopoly to becoming essentially an arm of the government that played a key role in stabilizing the slave trade in West Africa, supplied by new taxes on separate traders. ${ }^{107}$

Chamberlayne invalidated the Barbadian law that allowed people to be treated as simple property. When the Barbados' legislature sought to reenact their earlier detinue law of 1677, the "Act to revise and continue the Act to secure peaceable possession of slaves, and to punish the clandestine detinue of them," to re-establish "secure peaceable possession" of those they claimed as slaves, the Board of Trade under William II refused to ratify it. William III's Board of Trade overturned it twice between 1700 and 1702 . In 1702, when the assembly passed it a third time, the governor and council in Barbados rejected it on the grounds that it was "against H.M. [His Majesty's, King William's] Instructions," since any law that was rejected twice by the board could not be considered. ${ }^{108}$

The Council in Barbados also overturned some local cases that involved detinue or trover for slaves between and 1701 and 1708, which shows how routinely they were confronting these questions and that temporarily, at least the implications of Chamberlayne were being upheld in Barbados. So "Error brought by Thomas Walker, to reverse a judgment given against him on an action of detinue brought by Charles Wilson, senior, in H.M.

107. Price, "Credit in the Slave Trade," especially 304-6. One can imagine my surprise when I realized that the sharp shifts in the extension of credit for the purchase of slaves occurring in the colonies corresponded exactly with the legal cases that I had already discovered and discussed at length.

108. "Bill to continue an Act to secure the peaceable possession of negroes and other slaves to the inhabitants, and to prevent and punish the clandestine and illegal detinue of them, sent up, was read three times, passed, and received H.E. consent." (LATER REJECTED) Minutes of Council in Assembly of Barbados, January 21, 1701. TNA Catalogue Reference: CO 31/6, 389, 391. Minutes of Council in Assembly of Barbados, February 24, 1702. TNA CO 31/6, 167-70. CSPC Item 144, Vol. 20 (1702), 100-101. However it should be noted that the law did appear in the collection of Barbados laws published in 1704, so either it did pass afterward, or the publisher had an out of date copy of the laws, or someone, at that point, wanted the repeal ignored. 
[His Majesty's] Court of Common Pleas held for the precincts of Christ Church before [judge] Richard Elliot, for a negro woman and her three female children. Judgment reversed." $" 109$

The law reports of these King's Bench cases circulated widely and appeared in the libraries of judges in Virginia in the early eighteenth century. Robert "King" Carter, who was on the high court in Virginia from 1699 until his death in 1733, owned all the published English case reports, including those by Keble, Levinz, and many others. Judges in the colonies, especially on the high courts, learned much of what they knew of law from such printed sources, including treatises such as Coke's Institutes and Dalton's Country Justice. The elite also often sent their sons to learn at the Inns of Court, which took notes on King's Bench cases in particular, and circulated them, and some members of the Council in Virginia; for example, Edmund Jenings, who came to Virginia in 1680, had trained at the Inns of Court before they migrated. ${ }^{110}$

Holt presided over two more cases in which masters tried to invoke English property laws to regain men (or payments for men) whom they claimed as slaves. In these cases he upheld the verdict in Chamberlayne v. Harvey. The first, Smith v. Brown and Cooper, involved an attempt to collect a debt of $£ 20$ for the sale of a slave in London in 1701. Smith v. Brown and Cooper offered an opening for using "loss of services" as a potential form of recompense in some situations, but it was a narrow opening. To maintain such an action, one had to prove that one had a right to another's labor through a signed contract or deed. Then the claimant could get monetary damages.

Chief Justice Holt stepped in to invalidate the debt claim, to arrest the judgment, noting that "as soon as a negro comes into England, he becomes free." According to a report on the case published in 1718, some 8 years after his death, however, he supposedly also offered unofficial advice to the plaintiff, Smith, about how that claim might have been made valid.

You should have averred in the declaration, that the sale of the negro was in Virginia, and by the laws of that country negroes are saleable; for the laws of England do not extend to Virginia, being a conquered country their law is

109. Minutes of Council in Assembly of Barbados, August 5, 1701, TNA CO 31/6, 14 16. CSPC item 1160, Vol 19 (1701), 732.

110. All of the English reports that contain these cases were owned by Robert "King" Carter at his death in 1733, who was from 1699 a member of the council, which was also the high court (General Court) in Virginia. See the inventory of his estate, published in "Carter Papers," The Virginia Magazine of History and Biography (1898): 6:146. Also see the appendix to Brewer, By Birth or Consent, on which treatises were required by law to be available in early Virginia, for example, and which circulated most frequently in libraries. 
what the King pleases, and we cannot take notice of their law but as set forth: therefore he ordered the plaintiff should amend and alter his declaration, that the defendant was indebted to him so much, for a negro sold here at London, but that the said negro, at the time of the sale, was in Virginia; and that negroes by the laws and statutes of Virginia may be sold as chattels.

There's no doubt a political story behind the addition of those words to the formal report. If Holt stated them, he was raising important questions about whether these English cases did, after all, apply across the empire. If others added such words, those others were seeking to reconcile the legal implications of Chamberlayne across the empire with the desires of merchants and planters to make enslaved people collateral, especially in the colonies. $^{111}$

If Holt's supposed (and even if real, unofficial) advice had been the verdict (and it was not) Smith v. Brown and Cooper would have narrowed the application of Chamberlayne to England itself. The later report that included that sentence, published in 1718 at the height of the South Sea Bubble, which was partly fueled by the South Sea Company's involvement in slave trade with Spain, would seek to undermine the implications of the Holt Court decisions. Emphasizing that sentence almost made it possible then to reconcile the Holt court decisions with Butts v. Penny and other Stuart decisions; that attempt has been amplified in recent historiography. ${ }^{112}$ But that supposed recommendation by Holt must be read with caution. Holt's supposed advice would would have determined that the King's Bench — and the common law itself-had a limited reach. ${ }^{113}$ In practice, since the review process for colonial laws and court decisions went through William III's new Board of Trade and his Privy Council, which would and did generally adhere to the common law, it would have been a bizarre comment for Holt to have made. While Holt had acted as an advocate in 1685 for the East India Company and James II, which flirted with arguments

111. The aside appears in both, but is emphasized more in the later report, using the same words, discounting the ways in which the overall verdict denied that a person could be property. 2 Salkeld, 666. William Salkeld, Reports of cases adjudg'd in the Court of King's Bench . . . from the first year of K. William and Q. Mary, to the tenth year of Queen Anne (London: Eliz. Nutt and R. Gosling, 1718). Otherwise see Holt, KB, 494. A Report of all the Cases determined by Sir John Holt (London: Nutt \& Gosling, 1738), 494-95.

112. See, for example, Van Cleve, "Somerset's case and its antecedents"; and Bush, "Free to Enslave."

113. On the ability to appeal to the Privy Council, see Brewer, "Slavery, Sovereignty, and 'Inheritable Blood': Reconsidering John Locke and the Origins of American Slavery." Bilder, Transatlantic Constitution; Hulsebosch, Constituting Empire; and Sturtz, Within Her Power, who traces some cases that were appealed to the Privy Council from Virginia in the eighteenth century. In these cases, the Privy Council made decisions that referenced recent common law decisions. 
about separate powers for the company, he never argued that they operated outside the common law, and he then broke decisively with James II's absolutism. $^{114}$ It seems more than peculiar that after the Glorious Revolution, when he had rejected so much of the rest of absolutist arguments, he would suggest that the king had absolute power in Virginia.

In other case reports published during his lifetime, Holt specifically held that colonial law must be similar to English law. One of the most important examples was his ruling in May 1689 in a case that challenged the RAC's ability to use admiralty courts in Africa and in England's Americans colonies to confiscate the goods and ships of traders who interfered with its monopoly. Nightengale $v$. Bridges reversed a decision by an admiralty court at the RAC's headquarters in Africa from 1685. That ship, outbound from London, had been full of trade goods. Holt's court held that the admiralty court in Africa had acted contrary to English law. The ruling agreed with the plaintiff's lawyer that "in all Parts of the World where the Englishmen are under the Government of any English Subjects, their Rule must be the Law of this Land, and if they punish without Jury [as the Admiralty courts did], they may be punished for it by Action of Trespass when they return hither, and this we have in practice here very day in case of the insolency of Governors in Plantations, as in the East Indies and Barbados, and they cannot proceed there but in the methods allowed here." 115 Holt had then argued for comity between English and colonial law, and that actions of trespass, which would have included both detinue and trover, could be applied where appropriate. However note that the Nightengale case itself did not involve the question of whether people were property.

Smith v. Gould, Holt's last and most influential case involving slavery, echoed the verdict in Chamberlayne, limiting the ability to sell slaves, or to make a claim to sell slaves, even in the colonies. As in Smith v. Brown and Cooper, the Holt court also reversed a lower court decision, stopping or "arresting" a lower court's decision awarding the value of a negro at $£ 30$. It specifically negated the argument that "a negro was a chattel by the law of the plantations, and therefore trover would lie for him." Instead it returned to a simple and broad argument that "Trover does not lie for a negro," regardless of where that person is, because "the common law takes no notice of negroes being different from other men." The court

114. On the East India Company case, see Phil Stern, The Company State: Corporate Sovereignty and the Early Modern Foundations of the British Empire in India (Oxford: Oxford University Press, 2011). "John Holt" in ODNB.

115. Nightingale v. Bridges, published originally in The Reports of Sir Bartholomew Shower of cases adjudged in the Court of King's Bench (London: Browne \& Walthoe, 1708), 141. It appears (in a somewhat modified later edition) as 89 Eng. Rep. 496. 
continued that "by the common law no man can have a property in another" (the ruling in Chamberlayne). While they allowed that a limited property can be held in a villein, the only legal action allowed is the writ per quod servitiium amisit (loss of services), a writ that does not allow recovery of the person and is for a broken contract. The court, speaking in a per curium decision, then said unequivocally that Butts v. Penny was not law. Thus, a man who had lost goods and "a negro" could receive damages only for the goods. The "negro" was a man, and a man could not be stolen, and was not fungible or replaceable with money. "Men may be the owners, and therefore cannot be the subject of property." 116 Peter King, John Locke's protégé and later Lord Chancellor, took elaborate notes on this case, emphasizing and underlining many of the points that are quoted in the previously cited reports in his notebook. Many years later, it was this precedent, this case, and these words-long ignored - that would support the emancipation of James Somerset. ${ }^{117}$

Crucially, the slavery cases under Holt all held that one person cannot own another and that actions of trespass such as trover and detinue will not lie for a man, since a man is not a thing. They therefore repudiated slavery. In none of the three cases did the claimant of the supposed slave or of the debt for the sale of a supposed slave recover any money or the ownership of the man in question. It's crucial to note how political the interpretation of these cases became over time. Just as you or I pore over these reports, trying to discern their meaning for England and for the colonies,

116. In his "Lord Mansfield and the Legitimacy of Slavery in the Anglo-American World," Wiececk read this case somewhat differently, arguing that the judges must have agreed with some of the plaintiff's arguments that men "might be 'merchandize' like monkeys." In fact the citation that the plaintiffs made: the reference to monkeys as merchandise and the argument that "negroes" could also be merchandise, is to the Butts v. Penny case in 2 Lev. 201, 3 Keb. 785. The court explicitly denied that case and the logic. Directly after the plaintiff's argument where these words were summarized appears the phrase: "Sed Curia contra" (meaning the court says the opposite): The court then made some very narrow comments about villenage being possibly permitted, of which the trespass captium suum cepit was one possibility. However they firmly denied the legitimacy of Butts. As the other report concluded: "The Court denied the opinion in the case of Butts and Penny." Although one report of the case mentioned debate among the judges as to whether an ancient feudal writ might be used in a narrow way to claim that a "negro" belonged to someone, the court was clearly undecided on the issue. "The Court seemed to think that in a writ of trespass quare captivum suum cepit, the plaintiff might give in evidence that the party was his negro, and he bought him." This was at most a lukewarm endorsement of some level of ownership. The writ in question was even then rare; it was almost never used, as a search of English Reports shows.

117. Smith v. Gould, Ms Locke f. 39, 4-14. King's notes are unfortunately in shorthand, and it is hard to make out all of his commentary. But it is notable that it extended for ten pages. 
so did they then. What precedent did they give? Whose reports are best? Did Holt really say in 1699 that the colonies were "conquered" and that the king could make any law he wished? Did he doubt his own judgment in Smith v. Brown and Cooper, temporarily, and then double back later? These reports, and their interpretation, and the many notes on them by those students of the law over the next century, speak to the importance of court cases that set precedents.

The Holt court decisions made slave ownership in the colonies and in England itself less secure. Judges in colonial courts were constantly citing and quoting from published common law decisions, and colonial legislatures framed their laws around the common law. To do otherwise was to risk their very charters. Massachusetts and other colonies had passed laws that violated the common law, and their charters had been confiscated in the 1680s, just as Chief Justice Rainsford (among others) had recommended in 1677 . The idea that in the colonies there was a different law, as determined by the king, was generally rejected by the Holt rulings and by broader policies under William III and Anne. The perspective that all colonies had to conform to English law was the norm during Holt's tenure, from the court's recommendation in the Spanish case in 1689 to Smith v. Gould in 1706. While neither William nor Holt sought to enforce the full implications of the verdicts of these King's Bench cases in the colonies, these cases left their mark, and a legacy of uncertainty. The Board of Trade did overturn Barbados' Detinue Law in 1701 because it violated Chamberlayne v. Harvey, as shown. Colonial laws repugnant to the common law, as that was understood and interpreted, were likely to be vetoed by the Board of Trade, Privy Council, and king as in that case. Decisions repugnant to English law could be appealed to the Privy Council or to Common law and Chancery courts. ${ }^{118}$

When Virginia passed a law that turned slaves into real property in 1705 , so that their status was more like that of the supposed former status of villeins in England, they thereby avoided relying on trover, reverting to earlier, pre-Butts $v$ Penny norms. Barbados had been forced to rely on that norm earlier, in 1668, before trover was allowed. In both cases, I think, they were reacting to the uncertainty of the common and parliamentary law emanating from the empire. Virginia sought to quietly retain its detinue/trover norms in its 1705 law regardless. "That it shall and may be lawful, for any person, to sue for, and recover, any slave, or damage, for the detainer, trover, or conversion thereof, by action personal, as might have been done if this act had never been made." ${ }^{119}$ Much later,

118. Bilder, The Transatlantic Constitution; Hulsebosch, Constituting Empire.

119. Hening, Statutes at Large, 3:334. 
as a law student in the 1760 s, Jefferson would puzzle over these contradictions, citing the Holt court cases and then the 1705 law, and wondering whether Butts v. Penny still applied. "As soon as a NEGRo comes into England he becomes free: one may be a villein in England, but not a slave." Jefferson then cited the cases discussed previously, such as "Smith v. Brown \& Cooper. 2. Salk. 666" and wrote in the margin: "Q[uestion:] whether Virginia act of 1705. c.23. sect. viii any additional authority, which sais 'trover may be brought as before their act' trover will lie for a negro, for they are heathens, and therefore a man may have property in them. Gelly v. Cleve. . . . Butts v. Penny."120

After Holt's death, these radical cases began to be ignored and superseded. All those now involved in the slave trade (including the RAC and the new separate traders, as well as some colonial legislatures in the West Indies and in Southern colonies politically dominated by planters) tried to fill the hole that Holt's rulings had left, first with decisions and rulings in chancery, and most of all by reinvigorating Butts and the claims that slaves could be legally claimed as simple property. There is no question that in England itself, Holt and the high court had taken great strides to overturn the law of the Stuarts that had made slavery legal in England. In doing so they made slavery problematic everywhere.

At the same time, turning to villenage limited them, particularly their ability to buy and sell enslaved people, as it tied enslaved people to estates. During the eighteenth century, slaves could be - and were - entailed in both colonies, which proved problematic in the case of debt and limited sale. In 1727, Virginia modified the laws to permit entailed slaves to be sold to satisfy debts (and for that purpose to be considered "chattels") but it still limited their flexibility, as its effort to repeal the law that slaves could be entailed and held as real property in 1749 (an effort vetoed by George II) reveals most poignantly. ${ }^{121}$

A Common Pleas case from 1721, for example, cited the Butts (1677) and Gelly (1694) precedents, which had upheld trover for negroes, and misrepresented the Holt decisions. It stated simply: "Trover lies for muscheats [musk cats], monkies, parrots, for they are merchandise. . . And for negroes, for the same reason." ${ }^{, 122}$ That, I think, is the context for Holt's supposed aside in the Smith v. Brown and Cooper case, which

120. David Konig and Michael Zuckert, eds., Jefferson's Legal Commonplace Book (Princeton: Princeton University Press, 2019), 230-31.

121. See Holly Brewer, "Entailing Aristocracy in Colonial Virginia: 'Ancient Feudal Restraints' and Revolutionary Reforms," William and Mary Quarterly 54 (1997): 307-46, also Priest, "Creating an American Property Law" and Credit Nation, especially ch. 2.

122. Pickering v. Appleby in Common Pleas (1721) [Michaelmas term, 7 George I] 1 Comyns 354, 92 Eng. Rep. 1108. The text of the case cites Butts as its main precedent. 
was printed first in 1718, during the height of the South Sea Bubble. Upon the pleading of plantation owners and merchants in the colonies about the uncertainty created by the Holt rulings, justices in chancery in 1729 issued guidelines that reified the main point established by Butts: that people could be property. The two justices in this case, one of them the future Lord Hardwicke, went on to uphold these guidelines in case rulings, such as that in Pearne v. Lisle in 1749.

Meanwhile later reports of Butts appeared, including one by Richard Freeman in 1742, that reported its decision unproblematically, ignoring the decisions of the Holt era. The 1732 parliamentary law that established the ownership of slaves as property enshrined the Yorke-Talbot opinion of 1729 , and was perhaps the most crucial step in this process of legitimizing the principle that people can be owned as property and considered simply in that light. ${ }^{123}$

Still, by the mid-1730s, Virginia cases establishing slave ownershipwhen those slaves were not entailed-invoked the writs of trover and detinue almost exclusively. They were still following Butts v. Penny of 1677, as reaffirmed by the Parliamentary Act in 1732. These cases were routinely heard by lower courts, and occasionally made their way to Virginia's High, or General Court, where rulings were made by members of Virginia's council, also the most powerful slave owners. Although most such records burned, reports on some of those cases survive. So, in October 1729, for example, the Virginia case of Abbot vs. Abbot involved "trover for several negroes" and was decided for the defendant. Marston vs. Parrish (April 1730) centered on a writ of detinue involving several "Negroes." This case, as others, cited other detinue cases (involving property other than slaves) published in English reports unproblematically. Jones v. Langhorn and Andrew Giles \& Mary his Wife \& Mary Mallicote, plts and Palmer v. Word (October 1737) shows how pervasive

123. Pickering v. Appleby; see particularly footnote 1 "Holt Chief Justice declared, in the case of Chamerblain v. Harvey, 1 Raym. 147, that trover would not lie for a negro, and denied the authority of Butts v Penny, 2 Lev. 201. It was adjudged however in the common Pleas in the case of Gelly $v$. Cleve, that trover would lie for negroes, upon the ground of their being heathens, and that therefore a man might have property in them." Richard Freeman, Reports of Cases in Law and Equity: from 1670-1706 (London: Henry Lintot, 1742), 452. Note that Freeman's original report contained no citations or discussion, but that later editions, such as that included in the online version of English Reports (1 Freeman 452, 89 Eng. Rep. 338), which postdate Somerset, contain a long note that calls the original Keble report "curious" (perhaps because of the mention of $101 / 2$ slaves) and claims that Hargrave, Somerset's attorney, had examined the roll (records) in Butts and that "no judgment was ever given" in the case, citing $20 \mathrm{How}$. State Tri., 52. The efforts to discredit different common law cases over time are fascinating and illuminate the supple role of precedent. For the 1749 chancery case, see Pearne v. Lisle, Ambler, 76. 
such detinue cases involving slaves were; the General Court only heard the appeals. ${ }^{124}$ After 1732, contracts for the sale of slaves evolved to become longer, more formal, and more strictly enforced. ${ }^{125}$

The Virginia and Barbados examples reveal how these English decisions and imperial policies affected and reshaped the imperial order. Like Jefferson in the 1760 s, many other students of the law were copying out and annotating the English case law on these questions, trying to decide on the legitimacy and power of the legal arguments, and how different English common law decisions about the nature and status of persons could be invoked. ${ }^{126}$

In the early nineteenth century, Jacob Wheeler's Practical Treatise on American slave law cited many cases that used detinue; it was the most common procedure to establish ownership. Even in 1837, American law drew on different legal principles within common and civil law. Like the writs of detinue and trover, the writ de homine replegiando continued to be used in England and the American South for almost 200 years to recover slaves, although less frequently. From the master's perspective, de homine replegiando was dangerous, as it could be legally inverted to establish the rights of the so-called slave, as case law shows. It turned out - as apparently slaves and sympathetic lawyers gleaned that those who owned slaves could be imprisoned by this writ and that the capias in witheram, which still did not allow bail, could imprison "real masters." So as a South Carolina court pointed out in 1852 " . . . under the proceeding chosen in the present case, an absolute slave might be at large, on bail, and his master in custody." $" 127$ The general replacement of writs of trespass (trover, detinue) for writs that had feudal origins (de homine replegiando, habeus corpus) shows how much power masters gained from the transition that

124. For cases that the General Court (the high court) in Virginia heard, see, for example, in Randolph's reports Abbot vs. Abbot (1: R21); Marston vs. Parrish (1: R35); and Jones v. Langhorn (1: R109). In Barradall's reports, see Andrew Giles \& Mary his Wife \& Mary Mallicote, plts (1: B71); and Palmer v. Word (1: B289). All of these cases are in R. T. Barton, ed., Virginia Colonial Decisions: The Reports by Sir John Randolph and by Edward Barradall of Decisions of The General Court of Virginia 1728-1741 (Boston: Boston Book Company, 1909), 2 vols. The records of the General Court of Virginia burned in 1865; these reports are nearly all that survive of the original records on the general court of Virginia during the Colonial period.

125. Price, "Credit in the Slave Trade," especially 309-31.

126. David Konig and Michael Zuckert, eds., Jefferson's Legal Commonplace Book (Princeton: Princeton University Press, 2019), 230-231.

127. See Jacob Wheeler, A Practical Treatise on the Law of Slavery (New York and New Orleans: Craighead \& Allen, 1837), for example, 52, 62-65. Oaks, "Habeus Corpus in the States" especially 287, citing Huger v. Barnwell, 5 Rich 273 (SC 1852). 
began in 1677. They gained a much more absolute ownership in other people. $^{128}$

The definition of people as simple, absolute property in terms of establishing and protecting ownership meant that the whole panoply of property law that was being strengthened in Britain during this period could be applied to regulate slavery. Slaves could thereby be bought, sold, and recovered, and the loss of their labor could result in damages to the master. These rulings helped to distinguish English slavery and slave codes from those of other empires. While other empires created complex codes that in many ways recognized the humanity of the enslaved, allowing marriage, limiting separation of families, and allowing appeals of abuse to be heard in church courts, English law was less humane, more closed. The humanity of the enslaved was recognized mostly only in their responsibility for crimes. By so using the courts to enable a powerful corpus of law to extend to people, the Stuart kings used a sledgehammer to solve what should have been a subtle legal construction. Their attempt to evade Parliament led to absolutism in multiple dimensions.

Crucial to the ruling in Somerset - that James Somerset could not be recaptured by his owner in England in 1772, even though his owner claimed him as a slave-was the absolute erasure of Butts v. Penny as a precedent in England. Hargrave, Somerset's attorney, claimed to have examined the century-old roll (records) in Butts and that "no judgment was ever given" properly in the case. Therefore he argued, and Justice Mansfield of the King's Bench agreed, that Butts could never again be cited as a precedent in the English common law. This was a crucial point in reports of the case - and a point that modern historians have overlooked because we have not understood that Butts was ever precedent. This was a much stronger intervention than Holt's attempts in the earlier cases to reverse Butts and to claim that it was simply "not law." Erasing cases in a precedent-based system is extremely difficult, but Hargrave and Mansfield accomplished it, at least for England. ${ }^{129}$

Was Hargrave correct? Possibly. He seems to have based his claim on the fact that the determination was originally conditional: Levinz wrote that the court of King's Bench "gave judgment for the Plaintif, nisi Causa this Term; and at the end of the Term, upon the prayer of the Attorney General, to be heard as to this Matter, Day was given 'till next Term." Rainsford had made the judgment temporary, pending feedback from the attorney general (and Privy Council and Council on Foreign

128. Wheeler, A Practical Treatise, for example, 53, 63.

129. Somerset v. Stewart in Lofft. Hargrave's copy of Levinz, cited in the next note, is in the British Library. 
Plantations). That feedback was given and the case was apparently closed in July, although Keble kept the word "nisi" even when the case was closed "judgment for the plaintiff, Nisi." " Regardless, Butts was upheld over the next year in other cases, as I have shown, and it seems that it was settled law. While there might have been a minor error, the sense of the 1677 court was clear. Hargrave's claim was incorrect. But his suggestion of a technical error, of a temporary decision never revisited, provided enough of a possibility - a lifesaving branch as it were-for Mansfield to erase the precedent.

Still, Mansfield tried to limit the reach of his interpretation to England, neatly banishing this question about the ownership of people to the colonies alone. The real question, Mansfield held, was "whether any dominion, authority or coercion can be exercised in this country, on a slave according to the American laws." ${ }^{131}$ But as I have shown, local laws had previously been required to accord with English laws or be held repugnant. They were ratified within an imperial or federal framework, as was Barbados' 1677 detinue law, which was approved by the Council on Foreign Plantations after Butts v. Penny, or they were vetoed, as were thousands of colonial laws. In 1772, rather than seeing slavery as an imperial question, which it had so clearly been in 1677 , Mansfield was seeking to make slavery only a local law question. Mansfield's position was enabled by the Parliamentary Act in 1732 that allowed both servants and slaves in the colonies to be held as simple property for purposes of the recovery of debts. While the possibility of a separate law for the colonies was touted repeatedly after 1732, that became the formal position only after 1772. Mansfield took such a stand despite this vast repository of law that had been brought to bear imperially, to define and protect the property rights of slaveowners, and to define slaves as property. All of this history was conceptually erased in 1772, even though common law had been the buried and unseen foundation of the "local" laws and court decisions. Both had grown within a brew of constant interaction with imperial authorities. That erasure has powerfully shaped our own historiography.

The system of slavery that developed in the American colonies was actively encouraged by the imperial policy of Charles II and his brother James, acting partly through the bench, the "twelve judges in scarlet." The rulings from the bench legitimated enslaving non-Christians and

130. Creswell Levinz, The Reports of Sir Creswell Levinz, 2nd ed. In the Law French of Creswell's original notes it reads: "Et donc Judgment pur le Plaintiff nis caus cest Term. Mes al find del Term sur le prier del Attorney General, d'estre ousterment oye en le case, jour suit donc al prox' Term."

131. Somerset v. Stewart in Lofft, 17. Also see Wiecek, "Somerest: Lord Mansfield and the Legitimacy of Slavery." 
claiming them as property on the grounds that as non-Christians they were outside the protection of the common law, since it protected only subjects.

Holt's (and William III's) challenge in 1696 to the norms created by Rainsford (and Charles II) in 1677 came after 20 years of precedents that had cut a deep groove on the terrain of legal thought, an impact that proved persistent, powerful, and difficult to undo. Still, if judges who shared Holt's sentiments had continued to be appointed to the High Court, then slavery would not have been protected by the imperial laws of property in the same way, and this would have made its growth in the empire much more problematic and uncertain. Meanwhile, parallel attempts to undercut local laws regulating slavery in the empire, which originated in William III's new Board of Trade, also founded in 1696, were having their own impact. ${ }^{132}$

We all know the actual outcome. We know how African slavery developed in Barbados and Virginia, and in the empire. Our eyes look for the continuity, the source of what came later. And yet discontinuities are equally important. Even in the Butts case, the defense argued that one man could not own another and especially could not sell another, an argument that was repeated in many of these later cases, even in the seventeenth century and including the Chamberlayne case. So, although we know the outcome, the shape of "American slavery" was not predetermined. In all these cases, while one side claimed "negroes" as slaves, the alleged slaves had protectors. These protectors baptized them (in hopes that it would help them obtain freedom), funded them, propelled their cases before the High Court, and paid lawyers who argued on their behalf against basic principles of slavery and sale. These cases display - especially in a context in which power was so intertwined with slavery - the shape of the debate over fundamental questions of justice and morality during this period, assumed to be a time when no one questioned principles of enslavement. But of course they did. That is a crucial explanation for why slavery and servitude itself evolved differently in different colonies and in England itself and over time. ${ }^{133}$

This article has shown how critical it was to create a common law of slavery in the British Empire, one that would cover the transport and sale of slaves between colonies, regulate trade and confirm ownership. It needed to establish basic principles that made their status hereditary (like

132. Brewer, "Slavery, Sovereignty, and 'Inheritable Blood."”

133. One of my favorite things about Tomlin's Freedom Bound is how subtly he traces how norms of servitude and slavery developed in different colonies and states over time. The finer points of the law really mattered. I would emphasize that they were interconnected too, with the politics of those in power on the ground, as well with the judicial options created (and foreclosed) by England itself. 
that of villeins) but also turned them into "goods" (like things or animals). Fundamental choices set a precedent that endured, sometimes submerged and often forgotten and unseen by historians, for two centuries between 1660 and 1860 shaped by visions of a political order that idealized and manipulated an ancient feudal and Roman past. They converted these vestiges into newer principles of absolute monarchy, absolute power, and absolute property. These principles were challenged but then later affirmed in the empire, as they assumed new forms in the contest over principles of hierarchy and equality that engulfed most of the mainland colonies during the American Revolution.

While Somerset v. Stuart had also challenged whether black people could be considered villeins, that decision was rejected in the antebellum South on multiple grounds. ${ }^{134}$ Slavery, as a legal system that was hereditary, remained in some ways, according to Southern legal commentators, "a fragment of feudalism floating in the bosom of the nineteenth century." But it was more than that. The "feudalism" of the Stuarts was a bastard innovation associated with absolutism and with a particularly powerful form of capitalist ownership. The legal institution of slavery in the early nineteenth century retained hierarchies built into seventeenth-century absolutism, but also these legal contradictions, offering a counterpoint to the revolutionary practices of equality. Despite the tension within these different precedents, the complex web of legal legitimacy that the Stuarts helped to create by manipulating the law subordinated all members of society. These principles could be especially powerful against those who could be designated aliens, who could not claim the status of subjects and could be seen as outside the protection of the law.

Judges played a crucial role in a federal imperial system within which colonial legislatures and judges had to adhere roughly to common law norms, or be found repugnant. Charles II and James II appointed judges who swore oaths that they held their offices only at the bene placito, the "good pleasure," of the king (an expression widely associated with absolutism) and who made laws through the courts. These judges vastly expanded the power of ownership of people in 1677, creating the basis for a coherent slave code in England that allowed fuller ownership of human beings and protected such ownership in the courts. In doing so, they partly followed not only feudal precedents but also cases from the early seventeenth century that had allowed the ownership of animals. They cited these cases as precedents to roughly approximate the laws and practices of the Spanish and Portuguese Empires in the Americas whereby, they argued, "the

134. Rabin, "Slavery, Villeinage, and the Making of Whiteness"; Brewer, "Entailing Aristocracy." 
subjects of infidel princes" should be legally considered "goods" or "merchandise." While English judges were supposed to hold their tenure differently (during good behavior) after 1701 (the Act of Settlement), in the colonies, judges continued to hold their appointments at the pleasure of royal governors and the crown, one of the complaints in the Declaration of Independence.

The development of American slavery did not happen in an abstract state of nature within different colonies on their own, but within an imperial and political context. The most crucial rule that undergirded it, whether people could be property, was a legal fiction, the result of case law and imperial politics, and judges acting as policy makers. The American Revolution might seem to offer an escape from such a common law, one opened by Somerset. But American states with large populations of enslaved were also very vulnerable in times of war: only thirteen of Britain's forty colonies in the Americas rebelled; many of those that did not had substantial enslaved populations, and had real fears of rebellions that might repeat Tacky's revolt in Jamaica in $1762 .{ }^{135}$ And by the time of the Revolution, about half of all collateral for debt was secured by slave bodies. It is fascinating and disturbing how these issues (of debt and obligation, and of freedom and slavery) were negotiated in the Treaty of Paris of 1783 that ended the revolution. That is a story that I cannot tell fully here. But like the struggles over these questions, it remained political, and British norms of people as property in legal cases continued to have a powerful, if not omnipresent effect, even as enslaved black men and women in different states began to challenge them. Only by understanding this earlier period, can we make sense of the legal struggles over slavery in the wake of the American Revolution. ${ }^{136}$ The precedents, the actual writs

135. While Andrew O'Shaughnessy counts 26 colonies, my count is higher because I include every jurisdiction with a separate legislature or governing body as a colony, even if two jurisdictions share a governor. If one does not count that way, then Delaware (for example) was not a separate colony in 1776, but only part of Pennsylvania. See Andrew Jackson O'Shaughnessy, An Empire Divided: The American Revolution and the British Caribbean (Philadelphia: University of Pennsylvania Press, 2000); Vincent Brown, Tacky's Revolt: The Story of an Atlantic Slave War (Cambridge, MA: Harvard University Press, 2020).

136. Bonnie Martin, "Slavery's Invisible Engine: Mortgaging Human Property," The Journal of Southern History 76 (2010): 817-66. I should note that I've been thinking about this issue for a decade, and influenced by Bonnie's terrific work when I heard her present about it in about 2010 (before she published her article). Priest, Credit Nation. My argument complements that of Christopher Leslie Brown, Moral Capital: Foundations of British Abolitionism (Chapel Hill: UNC Press, 2006) which in some ways picks up the threads of the history where I end here. I am skeptical of the claims that Somerset seriously threatened the ownership of slaves in the colonies as long as the empire was intact, claims made in 
or processes, set by England's high court in 1677 still created and enforced legal ownership in antebellum Southern United States courts. While by then chattel slavery had largely lost sight of its ideological connection to absolutism, that is where it was born in the seventeenth century. Policies that had created property in people were a bizarre admixture of feudalism and capitalism, one antithetical to ideas and principles of democracy.

books like Alfred W. Blumrosen, "The Profound Influence in America of Lord Mansfield's Decision in Somerset v. Stuart Symposium Edition: Too Pure an Air: Law and the Quest for Freedom, Justice, and Equality: Essay," Texas Wesleyan Law Review 13 (2007/2006): 64558; Gerald Horne, The Counter-Revolution of 1776: Slave Resistance and the Origins of the United States of America (New York: NYU Press, 2014). On whether property in man was enshrined in the Constitution, I would note that while the Constitution did protect slavery in many key ways, as a variety of historians have shown, it did not do as much as the earlier common law and the 1732 Debt Recovery act had done. My argument here aligns somewhat with that of Sean Wilentz, No Property in Man (Cambridge, MA: Harvard University Press, 2018). For the last, there has been a burgeoning scholarship on freedom suits, for which I cannot possibly provide a comprehensive bibliography in this note. But see, for example, Emily Blanck, "Seventeen Eighty-Three: The Turning Point in the Law of Slavery and Freedom in Massachusetts," The New England Quarterly 75 (2002): 24-51; Andrew Fede, Roadblocks to Freedom: Slavery and Manumission in the United States South (New Orleans: Quid Pro Books, 2011); Kelly M. Kennington, St. Louis Freedom Suits and the Legal Culture of Slavery in Antebellum America (Athens: University of Georgia Press, 2017); and Anne Twitty, Before Dred Scott: Slavery and Legal Culture in the American Confluence, 1787-1857 (New York: Cambridge University Press, 2016). Fuente and Gross, Becoming Free, Becoming Black; Loren Schweninger, Appealing for Liberty: Freedom Suits in the South (Oxford: Oxford University Press, 2018); William G. Thomas, A Question of Freedom: The Families Who Challenged Slavery from the Nation's Founding to the Civil War (New Haven, CT: Yale University Press, 2020). 